\title{
The real effects of banking supervision: Evidence from enforcement actions
}

\author{
Journal of Financial Intermediation, forthcoming \\ Piotr Danisewicz \\ University of Bristol \\ School of Economics, Finance and Management, Tyndall Avenue, Bristol, BS8 1TH, United Kingdom \\ Danny McGowan \\ University of Nottingham \\ Business School, Jubilee Campus, Nottingham NG8 1BB, United Kingdom \\ Enrico Onali \\ Aston University \\ Business School, Birmingham, B4 7ET, United Kingdom \\ Klaus Schaeck* \\ Lancaster University \\ Management School, Bailrigg, Lancaster LA1 4YX, United Kingdom
}

\begin{abstract}
We present a novel way to examine macro-financial linkages by focusing on the real effects of bank supervisors' enforcement actions. Exploiting plausibly exogenous variation in supervisory monitoring intensity, we show that enforcement actions in single-market banks trigger temporarily large adverse effects for the macroeconomy by reducing personal income growth, the number of establishments, and increasing unemployment. These effects are related to contractions in bank lending and liquidity creation, and are more pronounced when we consider enforcement actions on both single-market and multi-market banks, and in counties with fewer banks and greater external financial dependence.
\end{abstract}

\section{Keywords: $\quad$ macro-financial linkages, real effects, economic growth, supervision, enforcement actions JEL codes: $\quad$ G21; G28; O43}

\footnotetext{
* Correspondence to: Klaus Schaeck, Lancaster University Management School, Lancaster University, Bailrigg, Lancaster LA1 4YX, United Kingdom. E-mail: k.schaeck@lancaster.ac.uk. We are grateful to an anonymous referee, Murillo Campello (the editor), Allen Berger, Bastian von Beschwitz, Martin Brown, Martin Cihak, Olivier de Jonghe, Hans Degryse, Bob DeYoung, Falko Fecht, Iftekhar Hasan, Jean Helwege, Kose John, Phil Molyneux, Alexander Ljungqvist, Lars Norden, Steven Ongena, Evren Ors, Kasper Roszbach, Robert Sauer, Günter Strobl, Greg Udell, Wolf Wagner, Larry Wall, and Qingwei Wang for stimulating discussions. We thank seminar and conference participants at Bangor Business School, at the Multinational Finance Meeting, Krakow, at the LAPE-FINEST Spring Workshop in Limoges, at the 5th International IFABS Meeting in Nottingham, at the European Financial Management Association Meeting in Reading, at the Financial Management Association European Meeting in Luxembourg, at the European Economic Association Meeting in Gothenburg, at the IBEFA Meeting at the Western Economic Association Meeting in Seattle, at the AIDEA-FINEST Meeting in Lecce, at the 5th EBC Tilburg University Conference on Financial Stability, at the CAREFIN Conference Bocconi University, at the conference "Indices of Riskiness: Management and Regulatory Implications" held at the Federal Reserve Bank of Atlanta, and at the Annual FMA Meeting in Nashville for helpful comments. Financial support from the British Academy (Grant No. SG120397) is gratefully acknowledged.
} 


\title{
The real effects of banking supervision: Evidence from enforcement actions
}

\begin{abstract}
We present a novel way to examine macro-financial linkages by focusing on the real effects of bank supervisors' enforcement actions. Exploiting plausibly exogenous variation in supervisory monitoring intensity, we show that enforcement actions in single-market banks trigger temporarily large adverse effects for the macroeconomy by reducing personal income growth, the number of establishments, and increasing unemployment. These effects are related to contractions in bank lending and liquidity creation, and are more pronounced when we consider enforcement actions on both single-market and multi-market banks, and in counties with fewer banks and greater external financial dependence.
\end{abstract}

Keywords: $\quad$ macro-financial linkages, real effects, economic growth, supervision, enforcement actions JEL codes: $\quad$ G21; G28; 043 
Do shocks to bank business activities caused by supervisory enforcement actions affect the macroeconomy? And if so, how large is the effect? Does it persist in the long run? How do competitor banks of the institutions that are affected by supervisory actions respond? Answering these questions is key to understanding macro-financial linkages. Moreover, it is also central to understanding how banks react to the supervisory environment. This is a timely question of relevance for academics, policymakers, and the public alike against the background of far-reaching changes in banking regulation following a wave of government interventions into financial systems globally, and the signing into law of the Dodd-Frank Wall Street Reform and Consumer Protection Act in the U.S. ${ }^{1}$

In this paper, we use shocks imposed on bank business activities via severe supervisory enforcement actions such as Formal agreements, Prompt corrective actions, and Cease and desist orders issued by the Federal Deposit Insurance Corporation (FDIC), the Federal Reserve System (Fed), and the Office of the Comptroller of the Currency (OCC) to identify their effect on a set of macroeconomic variables in U.S. counties through lending and liquidity creation. Such enforcement actions typically come in the aftermath of on-site inspections by regulators which follow a rotation rule that assigns federal and state regulators to the same bank at exogenously set time intervals (Agarwal, Lucca, Seru, and Trebbi (2014)).

To the extent that bank credit has no close substitutes as argued by Diamond (1984) and James (1987), we hypothesize that enforcement actions which affect the scope and scale of bank activities affect the macroeconomy. This reflects that enforcement actions typically reduce banks' ability to intermediate loans and deposits. Since banking markets are local in nature, we focus in our main tests on enforcement actions in single-market banks that operate within one county. Such clearly defined

1 Recent work by Ongena, Popov, and Udell (2013) points towards cross-border spillovers of banking regulation, and Giannetti and Simonov (2013) show that government interventions that restore capital requirements stimulate credit provision. In contrast, Duchin and Soysura (2014) highlight that government intervention via recapitalizations triggers unintended consequences. Upon receiving a bailout, U.S. banks originate riskier loans and invest into riskier securities. 
geographical boundaries avoid noise from spillovers across counties and help identification. As we show in this research, our results remain intact when we extend our analyses to allow for the impact of enforcement actions on multi-market banks.

We combine bank-specific data for 7,025 banks operating in 1,891 U.S. counties $(9,435$ county-year observations) with macroeconomic variables for the period 1999 to 2011 . For our tests that explore the transmission channel through which enforcement actions affect growth, we examine their effects on lending and liquidity creation. The latter is based on a new measure of bank liquidity creation (Berger and Bouwman, 2009). The basic intuition of this measure is that banks create liquidity by transforming illiquid assets into liquid liabilities.

To overcome the fact that economic growth, unemployment, and other macroeconomic variables as well as bank lending, and health are endogenously determined, our identification strategy relies on instrumental variables estimators. As described in greater detail in Section 2.2 below, we exploit plausibly exogenous variation in supervisory monitoring intensity which is reflected in the one, two, and three year lagged differences of the assignment of Less severe enforcement actions and in the lagged difference of the Severe enforcement action dummy.

Our main result suggests that severe enforcement actions which impose restrictions on bank activities such as deposit taking and origination of credit exert significantly negative effects on real per capita personal income growth, the number of establishments per 100 inhabitants, and the unemployment rate. The effects are substantial in terms of economic magnitudes: Severe actions are associated with a 0.70 percentage point reduction in personal income growth, and the number of establishments per capita declines by 0.02 percentage points when regulators issue severe enforcement actions. The unemployment rate increases by 0.16 percentage points. These results are similar when we use OLS, and remain unaffected by the inclusion of control variables. A first extension of our main 
analysis reiterates these inferences for a sample comprising multi-market banks, and a further extension shows that the effects of regulatory enforcement actions are limited during crises.

An exploration of the transmission mechanism suggests that these macro-financial linkages are attributable to contractions in bank lending. We observe considerable reductions in consumer lending, in credit supply to the commercial and industrial sector, and commercial real estate lending also contracts. Since bank lending neither considers the full scale of banks' intermediation activities nor considers off balance sheet activities such as lines of credit and guarantees, we additionally examine liquidity creation. This analysis highlights that liquidity creation, especially on the asset side of the balance sheet, contracts even more in response to severe enforcement actions than does bank lending.

To sharpen causal inference, additional tests that exploit information on the number of banks and the scope of external financial dependence of non-financial firms on the county level further strengthen our results. We show that the adverse macroeconomic effects are more pronounced in counties with fewer banks, suggesting that a lack of alternative sources of funds matters for the transmission of shocks from the banking industry to the real economy. Similarly, we find that the macroeconomy contracts more in counties whose industries are more reliant on external financing.

Our final set of tests focus on the long run and the behavior of competitor banks. We illustrate that the adverse effects for the real economy are only observable immediately after the announcement of enforcement actions but cannot be documented in the three subsequent years. Competitor banks, defined as those institutions located in the same county, do not increase lending or liquidity creation.

This research is related to several strands of literature. A few studies examine the direct effects of enforcement actions which can range from civil money penalties to restrictions on services such as deposit taking or provision of credit. Peek and Rosengren (1995, 1996) demonstrate that loan portfolios shrink following enforcement actions in the U.S. Recent work by Delis, Staikouras, and 
Tsoumas (forthcoming) also examines enforcement actions in the U.S. They show that asset quality of banks subject to supervisory enforcement actions declines. Using data for Germany, Berger, Bouwman, Kick, and Schaeck (2016) document that supervisory interventions disrupt liquidity creation. Most closely related to our paper is work by Berger and Roman (forthcoming). They take a macroeconomic perspective, and show that TARP resulted in significant increases in net job creation, more establishments, and reductions in bankruptcies.

Our work is also related to the studies on the real effects of bank distress, and research that analyzes how credit and liquidity supply shocks to banks transmit to the real sector. Bernanke (1983), and Calomiris and Mason (2003) show loan supply shocks reduce local economic output, and more recent research documents that bank failures reduce county income and reduce physical output (Ashcraft, 2005; Ziebarth, 2013). A larger number of studies focuses on how corporate investment and access to credit deteriorate when banks' liquidity supply contracts (e.g., Peek and Rosengren, 1995, 1996; Gan, 2007; Khwaja and Mian, 2008; Paravisini, 2008; Chava and Purnanandam, 2011; Schnabl, 2012). In contrast, the literature on how bank bailouts affect banks' borrowers is very limited. Norden, Rosenboom, and Wang (2013) show that capital injections in the U.S. trigger positive stock return responses by these banks' borrowers. Our paper distinguishes itself from these studies by focusing on a new type of shock arising from supervisory enforcement actions. ${ }^{2}$

Section 1 discusses the institutional background. Section 2 describes the dataset, and offers a preliminary investigation of basic statistics and our identification strategy. We present results in Section 3. Section 4 offers concluding remarks.

2 Recent work by Berger and Roman (2015) and Calderon and Schaeck (forthcoming) examines how government interventions in the form of capital support affect banking competition. 


\section{Institutional Background: Enforcement Actions}

In pursuing the aim to maintain a safe and sound banking system, different agencies (FDIC, Federal Reserve System, and OCC) are charged with bank supervision. One of the key tools to achieve this aim are on-site examinations. In instances when these on-site examinations suggest unsafe, unsound, or illegal practices which violate laws, enforcement actions are used to restore safety and soundness by altering bank practices, stabilising the institution, and averting losses to the deposit insurer (Curry, O'Keefe, Coburn, and Montgomery, 1999). Typical reasons for the initiation of enforcement actions are management problems (poor loan administration, insufficient corporate planning, poor internal controls), and financial problems (inadequate capital and inadequate loan loss reserves, poor asset quality, clustering of loan portfolio risks, failure to charge off loan losses, poor liquidity, insider payments, failure to file with regulators). Noncompliance with enforcement actions can result in termination of deposit insurance. Since banks understand that their asset choices determine supervisory closure rules, enforcement actions are likely to trigger changes in conduct (Mailath and Mester, 1994).

Several different enforcement actions exist. For our analyses, we group them together into Less severe actions and Severe actions based on their seriousness, disclosure requirements, whether they can be enforced in court, and based on whether they have potential to affect the scope and scale of bank activities (Curry et al., 1999; Ioannidou, 2005). Our grouping reflects both supervisory practice in the U.S., and also considers the Basel Core Principles for Effective Banking Supervision, issued in 2012. We now list the actions in ascending order.

The following types of actions are classified as Less severe actions.

Civil money penalties are imposed for violations of laws, regulations, Cease and desist orders, or Formal Agreements. They are publicly known. Typical penalties relate to violations of the Bank 
Secrecy Act, the Home Mortgage Disclosure Act, and to Call Report infractions. This type of enforcement action carries charges from $\$ 1,000$ to $\$ 1$ million per day, depending on the severity.

Suspension, removal, and prohibition orders allow regulators to bar individuals from associating with a bank due to violation of laws, regulations, or other written agreements. ${ }^{3}$ These actions are disclosed and publicly available. A typical civil money penalty that in our example also goes hand in hand with a removal and prohibition order reads as follows:

"WILLIAM BEN DUPREE, III ("Respondent”) has received a NOTICE OF INTENTION TO REMOVE FROM OFFICE AND PROHIBIT FROM FURTHER PARTICIPATION AND NOTICE OF ASSESSMENT OF A CIVIL MONEY PENALTY, FINDINGS OF FACT AND CONCLUSIONS OF LAW, ORDER TO PAY AND NOTICE OF HEARING issued by the Federal Deposit Insurance Corporation ("FDIC") detailing the violations of law or regulation, unsafe or unsound banking practices and/or breaches of fiduciary duty for which an ORDER OF REMOVAL FROM OFFICE AND PROHIBITION FROM FURTHER PARTICIPATION AND ORDER TO PAY A CIVIL MONEY PENALTY (the "ORDER") may issue, and has been further advised of the right to a hearing on the alleged charges under sections $[\ldots] ., 4$

We consider the following enforcements as Severe actions, all of them are disclosed.

Formal (written) agreements are bilateral agreements between the bank and the regulator which set out details on how to correct conditions which are the basis for the agreement. This type of enforcement action is not followed by a federal court case verdict.

Cease and desist orders are issued following hearings. Unlike Formal agreements, they are imposed on the bank by the regulator. Cease and desist orders, can come in the form of restrictions on bank activities, e.g., on asset growth and the prohibition of asset disposals. Moreover, Cease and desist orders go beyond the restriction of activities and usually require remedial actions to correct violations of laws and improve safety and soundness of the institution. Unlike Formal agreements, they can be enforced in court.

3 Note that when illegal actions of individuals threaten the safety and soundness of the bank itself, a Cease and desist order or a Formal agreement will be issued against the institution as well.

4 The entire document with the Order of Removal from Office and Prohibition from Further Participation and Order to pay a Civil Money Penalty can be downloaded from https://www5.fdic.gov/edo/DataPresentation.html using docket number: FDIC-10-624k. Our manual search for a variety of other enforcement actions suggests the details of this removal and prohibition order are representative. 
Prompt corrective actions are imposed on undercapitalized banks. This action demands corrective measures to restore adequate levels of capital, and requires submission of a capital restoration plan within a predetermined time period. Depending on the level of undercapitalisation, Prompt corrective actions can trigger dismissals of senior executives, and carry restrictions on executive pay, asset growth, and prohibition of: acquisitions, establishing new branches, issuing new lines of credit, selling company shares, and disposing assets.

Deposit insurance threats are the most severe enforcement action before a bank is placed in receivership, which leads to termination of the banks' charter or sale to other investors.

A typical severe action which details the requirements for capital restoration plans, limits on capital disbursements, asset growth, and also contains restrictions on bonus payments, reads as follows:

"[...] 1. The Bank shall no later than 60 days of the date of this Directive (or such additional time as the Board of Governors may permit):

a) Increase the Bank's equity through the sale of shares or contributions to surplus in an amount sufficient to make the Bank adequately capitalized as defined in section 208.43(b)(2) of Regulation H of the Board of Governors (12 C.F.R. § 208.43(b)(2));

$[\ldots]$

2. The Bank shall comply fully with the provisions of section 38(d)(1) of the FDI Act (12 U.S.C. § 1831o(d)(1)) restricting the making of any capital distributions, including, but not limited to, the payment of dividends.

3. The Bank shall not, without the prior written approval of the Federal Reserve Bank of Richmond (the "Reserve Bank") and the fulfillment of one of the requirements set forth in paragraph 1, solicit and accept new deposit accounts or renew any time deposit bearing an interest rate that exceeds the prevailing effective rates on deposits of comparable amounts and maturities in the Bank's market area.

5. The Bank shall comply fully with the provisions of sections 38(f)(4)(A)(i) and (ii) of the FDI Act (12 U.S.C. $\S \S 1831 \mathrm{o}(\mathrm{f})(4)(\mathrm{A})(\mathrm{i})$ and (ii)) restricting the payment of bonuses to senior executive officers and increases in compensation of such officers.

6. The Bank shall comply fully with the provisions of sections 38(e)(3) and (4) of the FDI Act (12 U.S.C. §§ $1831 \mathrm{o}(\mathrm{e})(3)$ and (4)) restricting asset growth, acquisitions, branching, and new lines of business. [... ${ }^{35}$

5 The full text document with additional details for this Prompt corrective action can be downloaded from http://www.federalreserve.gov/newsevents/press/enforcement/enf20110811a1.pdf. We verify with a manual search that this example is highly representative for other severe enforcement actions. 
Table 1 provides an overview about enforcement actions in single-market banks. In total, we observe 1,129 Less severe actions and 1,530 Severe actions. We record 744 Formal agreements. Cease and desist orders account for 911 observations, and there are 46 Prompt corrective actions (some of the banks received actions simultaneously). Regulators have not issued Deposit insurance threats during the sample period for single-market banks. ${ }^{6}$

[TABLE 1: Time distribution of enforcement actions]

\section{Data Description and Identification Strategy}

We obtain Call Report data for all commercial and savings banks in the U.S. from SNL Financial. This database also contains information about the timing and types of enforcement actions, branch location information, and deposit market shares from the Summary of Deposits from the FDIC. Our main regressions focus on the period 1999-2011, excluding the 2000-2002 and 2007-2009 crisis periods as our main tests examine the effects of enforcement actions during normal periods rather than during crises. To examine whether regulatory enforcement actions trigger differential effects during crises, we focus in separate analyses on the years 2000-2002 and 2007-2009 because these years are classified by Berger and Bouwman (2013) as crisis episodes.

Our main analyses examine enforcement actions in banks that operate in only one market, referred to as single-market banks, to allow a better demarcation of the boundaries of the relevant market for which we try to establish the real effects of enforcement actions. Our choice is predicated on the basis that where enforcement actions cause economic disruption, their real effects will be limited to the county where the single-market bank operates, allowing for a cleaner identification because of geographic market segmentation. This segmentation considers findings by Samolyk (1994)

6 All our tests exclude banks from Delaware and South Dakota. Delaware has about 20 times more incorporations than other U.S. states due to favorable legal treatment of incorporations, and South Dakota has a very large number of credit card banks incorporated resulting in a skewed distribution of measures of banking system structure there. 
who documents the importance of conditions in the local banking sector for explaining personal income growth. Such a regional credit view highlights localized information costs which arise from the low spatial mobility of bank customers and the information asymmetries inherent in lending relationships (Adams et al., 2007; Felici and Pagnini, 2008). Consequently, the natural unit of analysis is the county. We define a single-market county as a county that has at least one single-market bank in each year. Figure 1 illustrates that the majority of counties has at least one single-market bank and the number of counties with single-market banks is increasing over time. Figure 2 shows that there is no systematic clustering of counties in which enforcement actions took place.

\section{[FIGURE 1: Single-market banks]}

[FIGURE 2: Enforcement actions in single-market banks]

The econometric appeal arising from our focus on single-market banks however compromises the generalizability of our results with respect to large multi-market banks which may pose systemic risk. Therefore, we also present regressions that include enforcement actions on banks that operate across several different markets.

\subsection{Identification Strategy}

Endogeneity concerns between the macroeconomic environment and bank health, lending, and liquidity creation which arise primarily from the lack of random assignment of enforcement actions and the possibility of omitting time-varying, county-specific variables that may be coincident with the assignment of enforcement actions pose an identification problem: macroeconomic variables, bank behavior and supervisory actions are jointly determined. Naïvely regressing macroeconomic variables and bank lending and liquidity creation on enforcement actions will yield biased coefficients on the variables for the enforcement actions because the error terms will be correlated with the explanatory 
variable. This problem would render causal inference impossible because we do not observe the counterfactual. Even in the absence of actions by regulators, banks may recognize possible problems and alter their lending and liquidity creation. In the absence of a natural experiment, establishing causality therefore requires variables that explain enforcement actions but are neither correlated with the macroeconomic setting nor with bank behavior in terms of lending, liquidity creation, and the second-stage error term. For our main tests, we therefore use instrumental variables, and rely on a twostage estimator, and estimate the following equations.

$$
\begin{aligned}
& E A_{i t}=\alpha+\beta Z_{i t}+\delta X_{i t}+\gamma_{i}+\gamma_{t}+\varepsilon_{i t}, \\
& Y_{i t}=\alpha+\lambda E A_{i t}+\delta X_{i t}+\gamma_{i}+\gamma_{t}+\varepsilon_{i t}
\end{aligned}
$$

where $E A_{i t}$ denotes the enforcement action, represented by a dummy variable that takes on the value of one if a single-market bank was subject to a severe enforcement action in the county at time $t$ (zero otherwise); $Z_{i t}$ is a set of instruments; $X_{i t}$ is a vector of control variables, defined in detail below; $\gamma_{i}$ and $\gamma_{t}$ are county (bank) and year dummies, respectively. The term $\varepsilon_{i t}$ is the error term. We estimate the first stage with a linear probability model. All regressions are based on annual data. For completeness, we also present regressions based on OLS for our main analyses to understand the extent of the bias introduced by OLS.

Our tests below first focus on the macroeconomic setting. For these tests, the dependent variable $Y_{i t}$ represents personal income growth deflated using the CPI, the number of establishments, and the unemployment rate. ${ }^{7}$ For the tests on the bank level, the dependent variable represents bank lending, liquidity creation, and their respective components. There exist a number of difficult-toobserve variables which may affect both supervisory conduct and the macroeconomy over time (e.g.,

7 We obtain these variables from the Bureau of Economic Analysis, the Bureau of Labor Statistics, and the County Business Patterns database. 
during times of strain in the banking system regulators may be more prone to issue enforcement actions). We capture these time-invariant omitted variables by including county dummies, $\gamma_{i}$, and business cycle fluctuations common to all counties are captured by year dummies $\gamma_{t}$.

The vector of control variables $X_{i t}$ contains variables that can affect the macroeconomy and also matter for bank lending and liquidity creation. Cross-sectional variations are differenced out via our county- (bank-) fixed effects which net out differences in taxation across states that affect entrepreneurial activity, and we use year-fixed effects that take out the variation in demand conditions across the business cycle (Black and Strahan, 2002). The Z-score, defined as the ratio between a banks' return on assets and its capital ratio dived by the standard deviation of its return on assets, is included to consider bank soundness. This measure is an accounting based measure of a bank's distance to default (Laeven and Levine, 2009). We use this variable because bank soundness is reflective of the location of a bank, in particular when dealing with banks that operate in geographically delimited areas. Moreover, we use a Herfindahl-Hirschman Index (HHI) for deposit market shares to control for market structure, and we also account for average firm size (ln). Both variables are skewed and we therefore take the natural log. We use this variable to control for the firm structure of the non-financial sector because counties with on average larger firms are likely to grow faster as these are typically highproductivity firms (Helpman, Melitz and Yeaple, 2004). Cetorelli and Strahan (2006) argue that competition in banking affects access to finance and consequently has ramifications on industry structure in the non-financial sector. Table 2 presents summary statistics.

[TABLE 2: Summary statistics]

\subsection{Instrumental variables}

Our identification strategy relies on four plausibly exogenous, yet simple instruments which vary across time and across our cross-sectional units. We argue that banks that were subject to Less 
severe enforcement actions that extend exclusively to banks' personnel such as fines, civil money penalties, suspension, removal, and prohibition orders which bar individuals from associating with a bank due to violation of laws, regulations, or other written agreements are good precursors to more severe bank problems. We use the first, second, and third lags of the first-differences of a dummy variable for these Less severe enforcement actions as instruments for severe enforcement actions. ${ }^{8} \mathrm{We}$ use lagged first-differences rather than levels of the dummy for the Less severe enforcement actions to capture switches between states, which suggest an increase/decrease in the level of supervisory monitoring on the bank. ${ }^{9}$ Because the effect of an increase in monitoring can persist for several years, we employ three lags of the first-difference of Less severe actions. Since these types of enforcement actions only relate to individuals, they are neither affected by nor affect the economy as a whole, nor are such actions likely to trigger adjustments in bank behavior. Thus, they are good candidates to meet the identifying assumptions for valid instruments. Moreover, while Less severe actions may be more likely in counties with worse economic conditions (i.e., in poorer counties, banks' personnel may be more likely to breach regulations), it is unlikely that switches between states are related to short-term changes in local economic conditions.

Using the lagged differences of Less severe enforcement actions also ensures satisfaction of the exclusion condition even when the unit of our analysis is the individual bank in the regressions that focus on bank lending and liquidity creation. While the behavior of key employees can affect bank

8 Our Appendix A.1 documents that less severe enforcement actions correlate positively with severe enforcement actions but severe enforcement actions do not trigger less severe enforcement actions.

9 Note also that using lagged differences of these actions rather than the current levels excludes the possibility that our instruments are correlated with omitted variables related to local economic conditions (such as more corruption and fraud occurring in counties with low economic growth). For instance, consider the case of a county in which, because of a period of low economic growth for several years, people are more likely to commit fraud. In such a county, the dummy for Less severe enforcement actions is more likely to be equal to one than in counties with high economic growth for the current year. However, the first lagged difference of Less severe enforcement actions (which is constructed using the previous two years) will be zero for all the cases in which the levels take on the same value (either zero or one) in two consecutive years, excluding by construction the possibility to confound periods of low local economic growth with a sudden increase in the level of supervisory monitoring (the latter being the phenomenon we intend to capture with this instrument). 
conduct, it is plausible that the propensity of a bank employee to commit fraud is sluggish (i.e., it is unlikely that an individual is prepared to commit fraud in 2003, but not in 2004). A switch from zero to one in the value of the lagged differences of Less severe enforcement actions affects the probability of occurrence of a Severe enforcement action purely because of increased scrutiny from the regulators on the bank: Such stronger scrutiny and monitoring leads to a greater probability that regulators discover more severe problems in the bank, relative to banks that have not been subjected to a Less severe enforcement action. Therefore, the lagged differences of Less severe enforcement actions satisfy the exclusion restriction even for our bank-level regressions. With similar arguments, we also employ as an additional instrument the lagged difference of the Severe enforcement action dummy.

\section{Results}

This section first discusses our findings for single-market banks obtained with OLS and instrumental variables regressions. Next, we analyse whether multi-market banks respond differently to regulatory enforcement actions, and we also present tests that focus on crisis periods. Further subsections home in on potential mechanisms behind the effects on the macroeconomy, and we also explore whether counties with fewer banks and counties with firms that are more externally financially dependent are more affected by regulatory enforcement actions. The final set of analyses examines long-run effects and effects on competitor banks.

\subsection{Main results for single-market banks}

Table 3 presents our main results for the effect of severe enforcement actions on the macroeconomy using annual data. These regressions include county- and year-fixed effects and cluster heteroskedasticity-adjusted standard errors on the county level. Our subsequent tests for lending and 
liquidity creation include bank-and year-fixed effects. We cluster standard errors on the bank level to correct for serial correlation (Bertrand, Duflo, and Mullainathan, 2004).

Prior to presenting the findings obtained with the instrumental variables estimator, we present OLS results in Panel A of Table 3. This initial test suggests that personal income growth and the number of establishments contract significantly in response to severe enforcement actions, and the unemployment rate also increases significantly.

Next, we briefly mention the first stage results from our instrumental variables estimates. Panel B of Table 3 shows that the coefficients of all instruments enter at conventional levels of significance with the anticipated sign. The lags of the differences of the Less severe enforcement actions are all positive, and so is the lagged difference of the severe enforcement actions dummy.

The second stage results, presented in Panel C of Table 3 reinforce the findings from the OLS tests, and offer clear evidence that severe enforcement actions disrupt the real economy. Personal income growth, and the number of establishments are significantly reduced, and the unemployment rate increases following severe actions by regulators. ${ }^{10}$ The economic magnitude of these effects is substantial for all three macroeconomic variables. For personal income growth it is larger in terms of absolute values than in the OLS tests, indicating an upward bias in our OLS regressions. For the number of establishments and the unemployment rate the economic magnitude of the impact is smaller in terms of absolute values for the IV regressions than for the OLS regressions. Against an average growth rate of personal income of 1.7 percent, Severe enforcement actions reduce growth by 0.70 percentage points. Given an average number of 2.4 establishments per 100 inhabitants and an average unemployment rate of 6.01 percent, the coefficients indicate that severe actions reduce the former rate by 0.017 percentage points, and increase the latter rate by 0.157 percentage points. Thus, while the

10 We lose 6 observations in the regressions for the unemployment rate because data for these counties are missing. 
number of establishments is affected only to a limited extent, adjustments are made within firms by shedding workforce. This effect ultimately shows up in reduced growth. These magnitudes appear plausible. Ashcraft (2005) documents that bank failures result in declines of real economic activity measured by county personal income growth of 1.12 percent in the year of failure. Since our analyses do not consider the closure of a bank but rather the restrictions of activities, our figures are in the right ballpark.

To verify the choice of our instruments, we investigate several diagnostics. These tests reject underidentification of our models, and the Kleibergen Paap F-tests for weak identification likewise do not suggest that we suffer from weak instruments. The Hansen $J$-tests for the correlation between the residuals and the instruments support the validity of the exclusion restriction for the instruments. In addition, we also present $C$-tests (or difference-in-Hansen tests) to test for the exogeneity of each of the instruments (Brito and Bysted, 2010). This test is defined as the difference between the Hansen statistic in the equation with the smaller set of instruments and the equation including the instrument whose validity we want to test. Under the null hypothesis that both the smaller set of instruments and the suspect instrument are valid, the $C$-statistic follows a Chi-squared distribution. The results for these tests suggest that our instruments are valid.

[TABLE 3: Main results - The macroeconomic effects of enforcement actions]

Table 4 examines different types of enforcement actions, and presents coefficients for the effects of Formal agreements, Prompt corrective actions, and Cease and desist orders. Panel A shows the coefficients obtained with OLS. Formal agreements, Prompt corrective actions, and Cease and desist orders are all significantly negatively associated with personal income growth. Formal agreements and Cease and desist orders also significantly reduce the number of establishments, and Cease and desist orders significantly increase the unemployment rate. 
Panel B displays the first stage results from the corresponding instrumental variables estimator. A quick inspection of the diagnostics for the instrumental variables reinforces the choice of our instruments for Formal agreements and Cease and desist orders. Only for Prompt corrective actions do the test statistics point towards a problem of weak instruments. The Hansen $J$-test also displays weak significance at the ten percent level. This problem is due to the low number of these actions. During the sample period, regulators only issue 46 Prompt corrective actions.

Our Panel $\mathrm{C}$ of Table 4 reports on the second stage results. In a similar vein to the coefficients obtained with OLS, the instrumental variables regressions highlight that the magnitude of the effect on the macroeconomic environment depends on the type of enforcement action, and the coefficient magnitudes again differ between OLS and the estimates obtained in our instrumental variables regressions. Prompt corrective actions, despite being the type of action with the lowest frequency in our dataset, consistently display the largest effect, followed by Formal agreements, and Cease and desist orders. This pattern persists irrespective of whether we examine personal income growth, the number of establishments, or unemployment. These results are not surprising. Prompt corrective actions are the strongest types of enforcement actions, only occur rarely during the sample period, and 'hit' banks hardest. The stronger effect of Formal agreements in comparison to Cease and desist orders is also intuitive. Formal agreements are issued with the consent of the institution, suggesting a strong commitment by the bank to address the problems and respond quickly. Banks have strong incentives to avoid public attention from Cease and desist orders and are keen to portray themselves as adjusting behavior in line with mutual agreements with the regulator rather than being subject to Cease and desist orders. Moreover, Formal agreements tend to occur prior to Cease and desist orders, and many problem banks are examined at a high frequency which results in additional enforcement actions following Formal agreements. Thus, these two coefficients may pick up compounding effects. While 
Formal agreements are bilaterally agreed and are the first step to a change in conduct, Cease and desist orders may follow Formal agreements and have a lesser impact on banks.

[TABLE 4: Main results - The macroeconomic effects of different types of enforcement actions]

\subsection{Multi-market banks}

So far, we constrained our analyses to a sample of banks operating in single markets, denoted by county borders. This definition of the relevant market reduces the possibility that these banks make loans and create liquidity outside their local markets so that the causal effects of regulatory enforcement actions are most pronounced. From a regulatory and public policy perspective, however, large multi-market banks play a bigger role. We therefore now turn to an analysis of severe actions on both single-market and multi-market banks. In these tests, we extend our sample and additionally incorporate into the main sample observations for banks with multi-market operations to evaluate the incremental impact of enforcement actions on these banks.

Table 5 presents the results. In Panel A, we find that personal income growth again contracts, and the magnitude of the key coefficient is larger than in the instrumental variables tests for singlemarket banks. Likewise, the number of establishments also declines significantly in these tests. While the coefficient in the test for the unemployment rate remains positive, indicating an increase in unemployment, the $t$-statistic remains insignificant at conventional levels. The corresponding tests for the three different types of enforcement actions in Panel B of Table 5 also support the view that regulators' actions affect banks whose operations span multiple markets. Formal agreements, Prompt corrective actions, and Cease and desist orders reduce personal income growth. Formal agreements and Cease and desist orders also significantly reduce the number of establishments, and, correspondingly, increase the unemployment rate. In most instances, the magnitude of the coefficients is greater than in the tests for single-market banks. This is in line with economic intuition: 
multi-market banks have bigger operations that play a bigger role for the outcomes we study. The insignificance of Prompt corrective actions is a reflection of their low frequency.

[TABLE 5: The macroeconomic effects of enforcement actions (multi-market banks included)]

\subsection{Crises}

Our main analyses exclude the crisis periods 2000-2002 and 2007-2009. An important question is whether regulatory enforcement actions are stronger or weaker during crisis periods. In other words, it is crucial to understand if regulators' actions have 'more bite' during a crisis, or, alternatively, if interventions by regulators have a lesser effect during crises due to a variety of other government programs that coincide temporarily with enforcement actions. Prior work suggests a more limited effect of government interventions during crises. Berger, Bouwman, Kick and Schaeck (2010) show that interventions by German regulators into distressed banks have less pronounced effects on banks' liquidity creation during crises, and Berger and Bouwman (2013) demonstrate that monetary policy has a weaker effect on bank liquidity creation during such times.

Inspection of our descriptive statistics in Table 1 highlights that nearly 25 percent of all enforcement actions for the period 1999-2011 occur between 2007 and 2009. Moreover, Berger and Bouwman (2013) also classify the years 2000-2002, during which 19 percent of enforcement actions take place, as a crisis period. ${ }^{11}$ To understand whether the effects for the macroeconomy differ during crisis periods, we replicate our main regressions for the effects of Severe enforcement actions, and the three individual types of actions in Table 6. To preserve space, we only present the second stage results of the instrumental variables regressions.

11 Berger and Bouwman (2013) classify the years 2007-2009 as a period of a banking crisis while they consider the years 2000-2002 as a period with a market crisis, i.e., a crisis that occurred not in the banking sector but in the financial market with ramifications for the banking sector. In unreported tests, we obtain virtually identical results when we focus in our separate analysis for the crisis years only on the years 2007-2009. 
Panel A highlights that Severe enforcement actions have indeed less 'bite' during crises, consistent with prior literature. None of the macroeconomic indicators is significantly affected by regulatory enforcement actions. This result is largely confirmed when we offer a breakdown into Formal agreements, Prompt corrective actions, and Cease and desist orders in Panel B of Table 6. Only the unemployment rate significantly increases during crises, although the statistical significance of the coefficient estimates is smaller than in our main analyses. In addition, this finding is also likely to be the result of other forms of government intervention during crises that aim to boost the macroeconomy and consequently work in the opposite direction of enforcement actions. Importantly, Berger and Roman (forthcoming) show that the Troubled Asset Relief Program (TARP) during the recent crisis increased net job creation and net hiring establishments while it also decreased business and personal bankruptcies.

[TABLE 6: Crisis periods: The macroeconomic effects of enforcement actions (2007-2009)]

\subsection{Mechanism: Bank lending and liquidity creation}

What might drive these findings for the adverse effects of enforcement actions on the macroeconomy? Two key candidates that have potential to trigger macroeconomic contractions are bank lending and liquidity creation. The latter measure is based on Berger and Bouwman (2009), who propose a three-step procedure to compute liquidity creation. First, using information on the category and maturity of banks' assets and liabilities, we classify bank assets, liabilities and equity as liquid, semi-liquid, or illiquid depending on ease, cost, and time it takes customers to obtain liquid funds from the bank in case of liability items, and based on the ease, cost and time with which banks can dispose of their obligations in the case of assets. Second, we next assign weights of either $+1 / 2,0$, or $-1 / 2$ to all activities classified in the first step. The weights correspond to liquidity creation theory, which asserts that banks create liquidity by converting illiquid assets into liquid liabilities, whilst by transforming 
liquid assets into illiquid liabilities or equity, banks destroy liquidity. In the final step, we calculate how much liquidity each bank creates by combining and multiplying the activities classified in step 1 with the weights from step 2.

Our measure of liquidity creation is the preferred measure from Berger and Bouwman (2009) which classifies all activities other than loans by product category and maturity while loans are classified based on category due to data constraints. We also include off-balance sheet items, so that our measure of liquidity creation is identical to the measure termed 'cat fat' by Berger and Bouwman (2009). To verify our own computations do not differ from the original calculation of liquidity creation by Berger and Bouwman (2009), we examine the correlation between our measure 'cat fat' and the data reported on Christa Bouwman's website. ${ }^{12}$ The correlation is 0.97 with a $p$-value of 0.00 .

The tests in Table 7 report regressions for these possible mechanisms through which the severe actions by regulators might affect the macroeconomy. We first analyze bank lending and then liquidity creation. To this end, we run instrumental variable regressions on the bank level for 7,025 banks and use the same exogenous instruments and control variables as in the tests above. ${ }^{13}$ Panel A presents the first stage and Panel B focuses on the second stage.

In a similar vein to the first stage results shown above in Table 3 and 4, all instruments in Panel A enter significantly positively. The lagged differences of Less severe enforcement actions and also the lagged difference of severe enforcement actions significantly affect the probability of severe supervisory actions. Moreover, the diagnostics for the instruments confirm that our instruments satisfy both the relevance and the exclusion restrictions.

See http://web.mit.edu/cbouwman/www/data.html.

13 The number of enforcement actions in Table 7 is higher than those that enter the county-level analysis in Table 3 because in some counties multiple banks are subject to enforcement actions. 
Our first set of tests in Panel B highlights contractions in total lending growth with decreases of 8.3 percentage points in response to severe actions. A question that naturally arises then is whether all lending categories are affected equally or whether banks cut back their lending disproportionately for certain types of borrowers. ${ }^{14}$ The intuition is that loan categories reflect differences in risk choices and the most risky lending activities are likely to be most affected. To understand whether banks react in an intuitive manner, the next four columns show regressions with Corporate real estate loan growth, Residential real estate loan growth, Commercial and industrial loan growth, and with Consumer loan growth. The most standardized (Consumer lending), and the most risky lending activities (Commercial and industrial lending) are affected most prominently. The former contracts by 8 percentage points, and the latter is reduced by 10.2 percentage points. Corporate real estate lending is reduced by 6.6 percentage points. $^{15}$

While contractions in lending is a prime suspect, it only captures bank activities incompletely because off-balance sheet activities and lines of credit that are typically drawn down during a crisis are omitted when we examine lending activities (Ivashina and Scharfstein, 2010). If lending contracts in response to severe enforcement actions, the measure which captures intermediation activities more comprehensively should not only also contract but the magnitude of the effect should be even more pronounced. We consequently also examine liquidity creation.

The columns on the right hand side of Table 7 illustrate that our lending analysis underestimates the effects of enforcement actions. Banks reduce growth in liquidity creation by 12.1 percentage points when regulators issue a severe action. Our decomposition into growth in liquidity creation on the asset side, on the liability side, and off the balance sheet indicates that the driver behind

14 Appendix A.2 provides an overview about the distribution of lending activities across loan categories.

15 To rule out that banks which were supported by the Troubled Asset Relief Program confound our results as they may have been pressurized to lend, we remove in Appendix A.3 these banks. The results for lending and liquidity creation remain similar. 
this economically large effect is a contraction in liquidity creation on the asset side of the balance sheet with a magnitude of minus 26.8 percentage points. The coefficient for liquidity creation on the liability side is small with 6.6 percentage points, and liquidity creation off the balance sheet is not affected. ${ }^{16}$

[TABLE 7: Mechanism: The effects of enforcement actions on bank lending and liquidity creation]

\subsection{Complementary evidence: Tests based on bank representation and external financial dependence}

We exploit two cross-sectional predictions to present further evidence that enforcement actions affect the macroeconomy. The first prediction arises from the evidence above that lending and liquidity creation are reduced once regulators issue enforcement actions. Provided that some counties have more banks than others, one would expect macroeconomic contractions to be more pronounced in counties with fewer banks because the scope for firms to find alternative sources of financing is limited. To test this idea, Panel A of Table 8 shows regressions that constrain the sample to counties with low (high) representation of banks, defined as the number of banks being below the $25^{\text {th }}$ (above the $75^{\text {th }}$ ) percentile of the number of banks in the sample. We present the second stage results to preserve space.

The tests support this view. Personal income growth, the number of establishments, and the unemployment rate are significantly affected if bank representation is low, while the coefficients remain insignificant at conventional levels in counties where banks are well represented.

Our second test further sharpens identification using data from the County Business Patterns database using information on the composition of industries within counties. If the contraction in the macroeconomy is indeed a result of declines in lending and liquidity creation, the effects are likely to be heterogeneous across counties because some counties have industries that depend heavily on external financing whereas other counties may have industries that depend less on bank funding

16 Our inferences of the hypothesized mechanism remain very similar when we replicate the tests for lending, liquidity creation, and their components for both single-market and multi-market banks. To preserve space, these additional analyses are relegated to the Appendix, Table A.4. 
(Kroszner, Laeven, and Klingebiel, 2007). In counties where industries are more reliant on external financing, the macroeconomy should contract more in response to enforcement actions. Panel B in Table 8 shows second stage regressions from instrumental variables models that constrain the sample to counties where external financial dependence, calculated as in Rajan and Zingales (1998), is below (above) the $25^{\text {th }}\left(75^{\text {th }}\right)$ percentile of the distribution of this variable. ${ }^{17}$ The coefficient for severe actions behaves intuitively. Personal income growth, and the number of establishments contract significantly in counties where non-financial firms are strongly dependent on bank funding, and the unemployment rate increases significantly when regulators issue enforcement actions. In contrast, the effects are either insignificant or only weakly positively significant in counties with low dependence on external finance.

[TABLE 8: Complementary evidence: Analyses conditioned on bank representation and external

\subsection{Long-run effects and the behavior of competitor banks}

Our next test focuses on long-run effects. Provided that enforcement actions aim to correct an overexpansion of bank activities that is typically temporary in nature to ensure safe, sound, and sustainable future banking, it seems plausible to expect that enforcement actions do not trigger longrun effects for the real economy.

To this end, we replicate the main regressions from Table 3 but forward the dependent variable by one, two, and three years. Panel A in Table 9 presents the results. The coefficients on the Severe actions dummy are rendered insignificant, except for the dummy on the number of establishments at year $t+1$ and at $t+3$ where we are still able to document a contraction. Taken together, these tests

17 For brevity, we present in Table A.5 in the Appendix the corresponding analyses which include enforcement actions in banks that operate across county borders. This multi-market analysis yields similar results, and the macroeconomy remains more affected in areas with more limited bank representation and greater external financial dependence. 
suggest that the adverse effects from supervisory actions for the macroeconomy are typically only of temporary nature and do not tend to cause long-run harm for the real sector. ${ }^{18}$

A possible explanation for why there is relatively little evidence for effects of enforcement actions in the years following their announcement could be that distressed banks' competitors pick up business opportunities. If this conjecture is true, we should be able to document positive effects of severe enforcement actions on lending and liquidity creation among the competitors. Panel B in Table 9 shows regressions of the levels and growth rates of market shares in terms of lending and liquidity creation of the competitors from the same county. Competitor institutions do not significantly change their lending, and there are also no effects on their liquidity creation. ${ }^{19}$ Two explanations appear plausible. First, the relationship lending literature highlights the information sensitivity of banking. Repeated interaction between banks and borrowers may cause severe hold up problems and limits borrowers' propensity to switch (Sharpe, 1990; Ongena and Smith, 2001). Second, competitor banks may become aware of the enforcement actions at their distressed counterparts as enforcement actions are public. To avoid being subject to supervisory scrutiny, they may consciously shy away from filling the gap and forego the opportunity to extend their market shares.

[TABLE 9: Long-run effects and the behavior of competitor institutions]

\section{Concluding Remarks}

The key result in this paper suggests that enforcement actions by bank supervisors trigger temporarily adverse effects for the real economy. These effects, however, typically last for one year only, and recede afterwards.

18 Appendix Table A.6 reports the results of the long-run analysis for a sample comprising both single-market and multimarket banks. The findings remain similar. 
We document that Severe enforcement actions such as Formal agreements and Cease and desist orders imposed on single-market banks operating in U.S. counties reduce personal income growth rates by 0.7 percentage points, the number of establishments by 0.017 percentage points, and the unemployment rate increases by 0.157 percentage points, respectively. With growth rates averaging 1.5 percent between 1999 and 2011 (excluding crisis periods) on the county level, these effects are considerable in terms of magnitude. These results tend to be even more pronounced when we extend our analysis and include multi-market banks but they are less strong during the crisis episodes. Further tests show that these real effects are brought about by declines in bank lending and liquidity creation. In line with the idea that lending and liquidity creation are the key transmission mechanism by which shocks that affect individual banks propagate to the real economy, we show that counties with fewer banks and counties whose industries exhibit a greater dependence on external financing are more affected. A final analysis which examines the behavior of the distressed institutions' competitor banks offers no indication that they exploit the arising business opportunities and increase lending and liquidity creation.

Our research builds on a quickly evolving literature that analyses the effects of enforcement actions on distressed banks. Unlike other studies that focus on the effects of enforcement actions on the micro level, the main innovation in our work is that we are the first to show that local economic indicators respond to such supervisory actions. Our empirical framework is uniquely suited to highlight this important macro-financial linkage, and offers a starting point for future research to investigate further knock-on effects of regulatory enforcement actions for the macroeconomy. 


\section{References}

Adams, R. M., K. P. Brevoort, and E. K. Kiser (2007) 'Who competes with whom? The case of depository institutions', Journal of Industrial Economics, Vol. 55, pp. 141-167.

Agarwal, S., D. Lucca, A. Seru, and F. Trebbi (2014) 'Inconsistent regulators: Evidence from banking', Quarterly Journal of Economics, Vol. 129, pp 889-938.

Ashcraft, A. B. (2005) 'Are banks really special? New evidence from the FDIC-induced failure of healthy banks', American Economic Review, Vol. 95, pp. 1712-1730.

Berger, A. N., C. H. S. Bouwman, T. Kick, and K. Schaeck (2016) 'Bank liquidity creation following regulatory interventions and capital support', Journal of Financial Intermediation, Vol. 26, pp. 115-141.

Berger, A. N., C. H. S. Bouwman, T. Kick, and K. Schaeck (2010) 'Bank liquidity creation and risk taking during distress', Deutsche Bundesbank Series 2 Discussion Paper No. 2010, 05.

Berger, A. N., and C. H. S. Bouwman (2009) 'Bank liquidity creation', Review of Financial Studies, Vol. 22, pp. 3779-3837.

Berger, A. N., and R. Roman (forthcoming) 'Did saving Wall Street really save main street? The real effects of TARP on local economic conditions', Journal of Financial and Quantitative Analysis.

Berger, A. N., and R. Roman (2015) 'Did TARP banks get competitive advantages?', Journal of Financial and Quantitative Analysis, Vol. 50, pp. 1199-1236.

Bernanke, B. S. (1983) 'Nonmonetary effects of the financial crisis in the propagation of the Great Depression', American Economic Review, Vol. 73, pp. 257-276.

Bertrand, M., Es. Duflo, and S. Mullainathan (2004) 'How much should we trust differences-in-differences estimates?,' Quarterly Journal of Economics, Vol. 119, pp. 249-275.

Black, S. E., and P. E. Strahan (2002) 'Entrepreneurship and bank credit availability', Journal of Finance, Vol., 57, pp. 2807-2833.

Brito, R. D., and B. Bysted (2010) 'Inflation targeting in emerging economies: Panel evidence', Journal of Development Economics, Vol. 91, pp. 198-210. 
Calderon, C., and K. Schaeck (forthcoming) 'The effects of government interventions in the financial sector on banking competition and the evolution of zombie banks.' Journal of Financial and Quantitative Analysis.

Calomiris, C. W., and J. R. Mason (2003) 'Consequences of bank distress during the great depression', American Economic Review, Vol. 93, pp. 937-947.

Cetorelli, N., and P. E. Strahan (2006) 'Finance as a barrier to entry: Bank competition and industry structure in local U.S. markets', Journal of Finance, Vol. 61, pp. 437-461, 02.

Chava, S., and A. Purnanandam (2011) 'The effect of banking crises on bank-dependent borrowers', Journal of Financial Economics, Vol. 99, pp. 116-135.

Curry, T. J., J. P. O’Keefe, J. Coburn, and L. Montgomery (1999) 'Financially distressed banks: How effective are enforcement actions in the supervision process?', FDIC Banking Review, Vol. 12, pp. 1-18.

Delis, M., C., P. Staikouras, and C. Tsoumas (forthcoming) 'Formal enforcement actions and bank behavior', Management Science.

Diamond, D. W. (1984) 'Financial intermediation and delegated monitoring', Review of Economic Studies, Vol. 51, pp. 393-414.

Duchin, R., and D. Sosyura (2014) 'Safer ratios, riskier portfolios: Banks' response to government aid', Journal of Financial Economics, Vol. 113, pp. 1-28.

Felici, R., and M. Pagnini (2008) 'Distance, bank heterogeneity and entry in local banking markets', Journal of Industrial Economics, Vol. 56, pp. 500-534

Gan, J. (2007) 'The real effects of asset market bubbles: Loan- and firm-level evidence of a lending channel', Review of Financial Studies, Vol. 20, pp. 1941-1973.

Giannetti, M., and A. Simonov (2013) 'On the real effects of bank bailouts: Micro evidence from Japan', American Economic Journal: Macroeconomics 2013, Vol. 5, pp. 135-167.

Helpman, E., Melitz, M.J., and Yeaple, S.R. (2004) 'Export Versus FDI with Heterogeneous Firms', American Economic Review, Vol. 94, pp. 300-316. 
Ioannidou, V. P. (2005) 'Does monetary policy affect the central bank's role in bank supervision?' Journal of Financial Intermediation, Vol. 14 (2005) 58-85.

Ivashina, V., and D. S. Scharfstein (2010) 'Bank lending during the financial crisis of 2008', Journal of Financial Economics, Vol. 97, pp. 319-338.

James, C. (1987) 'Some evidence on the uniqueness of bank loans', Journal of Financial Economics, Vol. 19, 217-235.

Kedia, S., and S. Rajgopal (2011) 'Do the SEC's enforcement preferences affect corporate misconduct?', Journal of Accounting and Economics, Vol. 51, pp. 259-278.

Khwaja, A. I., and A. Mian (2008) 'Tracing the impact of bank liquidity shocks: Evidence from an emerging market', American Economic Review, Vol. 98, pp. 1413-1442.

Kroszner, R., L. Laeven, and D. Klingebiel (2007) 'Banking crises, financial dependence, and growth', Journal of Financial Economics, Vol. 84 pp. 187-228.

Laeven, L., and R. Levine (2009) 'Bank governance, regulation and risk taking', Journal of Financial Economics, Vol. 93(2), 2009, pp. 259-75.

Mailath, G. J., and L. J. Mester (1994) 'A positive analysis of bank closure', Journal of Financial Intermediation, Vol. 3, pp. 272-299.

Norden, L., P. Rosenboom, and T. Wang (2013) 'The impact of government intervention in banks on corporate borrowers' stock returns', Journal of Financial and Quantitative Analysis, Vol. 48, pp. 1635-1662.

Ongena, S., and D. C. Smith (2001) 'The duration of bank relationships', Journal of Financial Economics, Vol. 61, pp. 449-475.

Ongena, S., A. Popov, and G. Udell (2013) 'When the cat's away the mice will play: Does regulation at home affect bank risk-taking abroad?', Journal of Financial Economics, Vol. 108, pp. 727-750.

Paravisini, D. (2008) 'Local bank financial constraints and firm access to external finance', Journal of Finance, Vol. 63, pp. 2161-2193. 
Peek, J., and E. S. Rosengren (1996) 'Bank regulatory agreements and real estate lending', Real Estate Economics, Vol. 24, pp. 55-73.

Peek, J., and E. S. Rosengren (1995) 'Bank regulation and the credit crunch', Journal of Banking and Finance, Vol. 19, pp. 679-692.

Rajan, R., G., and L. Zingales (1998) 'Financial dependence and growth' American Economic Review, Vol. 88, pp. 559-586.

Samolyk, K. A. (1994) 'Banking conditions and regional economic performance: Evidence of a regional credit channel', Journal of Monetary Economics, Vol. 34, pp. 259 -278.

Schnabl, P. (2012) 'The international transmission of bank liquidity shocks: Evidence from an emerging market', Journal of Finance, Vol. 67, pp. 897-932.

Ziebarth, N. L., (2013) 'Identifying the effects of bank failures from a natural experiment in Mississippi during the Great Depression', American Economic Journal: Macroeconomics, Vol. 5: pp. 81-101. 
Table 1

Descriptive statistics for enforcement actions

\section{Panel A: Time distribution of enforcement actions in U.S. counties}

\begin{tabular}{|c|c|c|c|c|c|c|}
\hline \multirow{2}{*}{ Year } & \multirow{2}{*}{ Any action } & \multirow{2}{*}{ Severe actions } & \multirow{2}{*}{ Less severe actions } & \multicolumn{3}{|c|}{ Breakdown of Severe actions } \\
\hline & & & & Formal agreements & Cease and desist orders & Prompt corrective actions \\
\hline 1999 & 121 & 66 & 55 & 31 & 35 & 3 \\
\hline 2000 & 159 & 79 & 80 & 44 & 38 & 3 \\
\hline 2001 & 169 & 91 & 78 & 53 & 45 & 3 \\
\hline 2002 & 185 & 109 & 76 & 64 & 54 & 2 \\
\hline 2003 & 196 & 117 & 79 & 60 & 66 & 2 \\
\hline 2004 & 201 & 117 & 84 & 60 & 65 & 1 \\
\hline 2005 & 201 & 104 & 97 & 55 & 53 & 1 \\
\hline 2006 & 189 & 86 & 103 & 49 & 39 & 0 \\
\hline 2007 & 179 & 78 & 101 & 37 & 47 & 0 \\
\hline 2008 & 198 & 100 & 98 & 45 & 62 & 0 \\
\hline 2009 & 275 & 174 & 101 & 76 & 120 & 8 \\
\hline 2010 & 369 & 259 & 110 & 114 & 181 & 19 \\
\hline 2011 & 217 & 150 & 67 & 56 & 106 & 4 \\
\hline Total & 2659 & 1530 & 1129 & 744 & 911 & 46 \\
\hline
\end{tabular}

Panel B: Correlations between enforcement actions

Severe actions

Less severe actions

Formal agreements

Cease and desist orders

Prompt corrective actions

Severe actions 1

Less severe actions

$0.211 * * *$

(0.00)

Formal agreements

$0.690 * * *$

(0.00)

Cease and desist orders

$0.765^{* * * *}$

$(0.00)$

$0.170 * * *$

(0.00) mpt corrective action
0. $145 * * *$

(0.00)

$0.192 * * *$

(0.00)

$0.070 * * *$

(0.59)

Notes. Panel A presents the number of enforcement actions issued by bank supervisors in U.S. counties in the years 1999-2011 for single-market banks. We report the total number of enforcement actions (Severe and Less severe actions), the number of Severe actions (Formal agreements, Cease and desist orders, and Prompt corrective actions), and the number of Less severe actions. This latter category consists of Actions against personnel and individuals, and other Civil money fines. During our sample period, we observe no single Deposit insurance threat in single-market banks. Deposit insurance threats would also be classified as Severe actions. Enforcement actions in single-market banks in Delaware and South Dakota states are excluded. Panel B presents a correlation matrix for the different types of enforcement actions. $* * * \mathrm{p}<0.01, * * \mathrm{p}<0.05, * \mathrm{p}<0.1$. 
Table 2

\begin{tabular}{|c|c|c|c|c|c|c|}
\hline \multicolumn{7}{|c|}{ Summary statistics } \\
\hline Variable & Observations & Mean & S.D. & Min & $\operatorname{Max}$ & Source \\
\hline \multicolumn{7}{|l|}{ Dependent macroeconomic variables } \\
\hline Real per capita personal income growth & 9,435 & 0.015 & 0.036 & -0.077 & 0.126 & U.S. Bureau of Economic Analysis \\
\hline \# of Establishments (per 100 inhabitants) & 9,435 & 2.439 & 0.774 & 0.662 & 9.403 & County Business Patterns database \\
\hline Unemployment rate (in \%) & 9,429 & 6.226 & 2.502 & 1.100 & 29.900 & Bureau of Labor Statistics \\
\hline \multicolumn{7}{|l|}{ Dependent bank-level variables } \\
\hline Total lending growth & 33,678 & 0.069 & 0.189 & -0.308 & 0.966 & SNL Financial, authors' calculation \\
\hline Corporate real estate loan growth & 33,678 & 0.145 & 0.392 & -0.468 & 2.176 & SNL Financial, authors' calculation \\
\hline Residential real estate loan growth & 33,678 & 0.060 & 0.262 & -0.412 & 1.325 & SNL Financial, authors' calculation \\
\hline Commercial and industrial loan growth & 33,678 & 0.078 & 0.337 & -0.538 & 1.600 & SNL Financial, authors' calculation \\
\hline Consumer loan growth & 33,678 & -0.020 & 0.276 & -0.541 & 1.320 & SNL Financial, authors' calculation \\
\hline Liquidity creation growth & 33,678 & 0.117 & 0.394 & -1.000 & 1.666 & SNL Financial, authors' calculation \\
\hline Liquidity creation growth (asset side) & 33,678 & 0.079 & 1.188 & -4.317 & 4.592 & SNL Financial, authors' calculation \\
\hline Liquidity creation growth (liability side) & 33,678 & 0.106 & 0.225 & -0.335 & 1.192 & SNL Financial, authors' calculation \\
\hline Liquidity creation growth (off balance) & 33,678 & 0.171 & 0.423 & -0.559 & 1.794 & SNL Financial, authors' calculation \\
\hline \multicolumn{7}{|c|}{ Enforcement actions(lagged): county-level regressions } \\
\hline Severe actions & 9,435 & 0.085 & 0.278 & 0 & 1 & SNL Financial, authors' calculation \\
\hline Less severe actions & 9,435 & 0.053 & 0.224 & 0 & 1 & SNL Financial, authors' calculation \\
\hline Formal agreements & 9,435 & 0.042 & 0.200 & 0 & 1 & SNL Financial \\
\hline Prompt corrective actions & 9,435 & 0.003 & 0.056 & 0 & 1 & SNL Financial \\
\hline Cease and desist orders & 9,435 & 0.052 & 0.221 & 0 & 1 & SNL Financial \\
\hline \multicolumn{7}{|c|}{ Enforcement actions(lagged): bank-level regressions } \\
\hline Severe actions & 33,678 & 0.021 & 0.144 & 0 & 1 & SNL Financial \\
\hline Less severe actions & 33,678 & 0.015 & 0.121 & 0 & 1 & SNL Financial \\
\hline Formal agreements & 33,678 & 0.010 & 0.102 & 0 & 1 & SNL Financial \\
\hline Prompt corrective actions & 33,678 & 0.000 & 0.021 & 0 & 1 & SNL Financial \\
\hline Cease and desist orders & 33,678 & 0.015 & 0.123 & 0 & 1 & SNL Financial \\
\hline \multicolumn{7}{|l|}{ Control variables (lagged) } \\
\hline HHI deposits (ln) & 9,435 & -1.434 & 0.492 & -3.157 & 0.000 & SNL Financial, authors' calculation \\
\hline Firm size $(\ln )$ & 9,435 & 2.537 & 0.560 & 0.000 & 4.580 & Bureau of Labor Statistics \\
\hline Z-score $(\ln )$ & 9,435 & 4.540 & 0.986 & -0.871 & 37.468 & Authors' calculation \\
\hline Z-score (ln) bank-level & 33,678 & 4.104 & 1.113 & -3.590 & 38.854 & Authors' calculation \\
\hline
\end{tabular}

Notes. The table presents summary statistics, means, standard deviations, minima, maxima and the data sources for county-level variables (for counties with at least one singlemarket bank) and bank-level variables (for single-market banks). Sample period: 1999-2011 (2000-2002 and 2007-2009 excluded). 
Table 3

Main results: The macroeconomic effects of supervisory enforcement actions

\begin{tabular}{|c|c|c|c|}
\hline \multicolumn{4}{|c|}{ Panel A: OLS regressions } \\
\hline Dependent variable & Personal income growth & \# of Establishments & Unemployment rate \\
\hline L.Severe actions & $\begin{array}{c}-0.005^{* * * *} \\
(-3.423)\end{array}$ & $\begin{array}{c}-0.020^{* * * *} \\
(-3.736)\end{array}$ & $\begin{array}{l}0.184^{* *} \\
(2.501)\end{array}$ \\
\hline L.ln(Z-score) & $\begin{array}{c}0.002 * * * \\
(4.872)\end{array}$ & $\begin{array}{c}0.003 \\
(1.366)\end{array}$ & $\begin{array}{l}-0.124 * * * \\
(-4.556)\end{array}$ \\
\hline L. $\ln (\mathrm{HHI})$ & $\begin{array}{l}0.005 \\
(1.559)\end{array}$ & $\begin{array}{c}0.038^{* * * *} \\
(2.856)\end{array}$ & $\begin{array}{l}-0.185 \\
(-1.052)\end{array}$ \\
\hline L.ln(Firm size) & $\begin{array}{c}0.007 * * * \\
(3.416)\end{array}$ & $\begin{array}{c}0.030 * * * \\
(5.074)\end{array}$ & $\begin{array}{l}-0.588 * * * \\
(-7.969)\end{array}$ \\
\hline Year FE & Yes & Yes & Yes \\
\hline County FE & Yes & Yes & Yes \\
\hline Observations & 9,435 & 9,435 & 9,429 \\
\hline$R$-squared & 0.035 & 0.344 & 0.720 \\
\hline Counties & 1,891 & 1,891 & 1,891 \\
\hline Number of actions & 798 & 798 & 796 \\
\hline \multicolumn{4}{|c|}{ Panel B: IV regressions - First stage } \\
\hline Dependent variable & L. Severe actions & L. Severe actions & L. Severe actions \\
\hline L.ln(Z-score) & $\begin{array}{l}-0.006 * * \\
(-2.536)\end{array}$ & $\begin{array}{c}-0.006^{* *} \\
(-2.536)\end{array}$ & $\begin{array}{c}-0.006 * * \\
(-2.524)\end{array}$ \\
\hline L.ln(HHI) & $\begin{array}{l}-0.047 * \\
(-1.793)\end{array}$ & $\begin{array}{l}-0.047^{*} \\
(-1.793)\end{array}$ & $\begin{array}{l}-0.048^{*} \\
(-1.828)\end{array}$ \\
\hline L.ln(Firm size) & $\begin{array}{c}-0.039 * * * \\
(-3.129)\end{array}$ & $\begin{array}{c}-0.039^{* * * *} \\
(-3.129)\end{array}$ & $\begin{array}{l}-0.039^{* * * *} \\
(-3.124)\end{array}$ \\
\hline LD.Less Severe actions & $\begin{array}{c}0.041^{* * * *} \\
(2.588)\end{array}$ & $\begin{array}{c}0.041^{* * * *} \\
(2.588)\end{array}$ & $\begin{array}{c}0.041^{* * * *} \\
(2.587)\end{array}$ \\
\hline L2D.Less severe actions & $\begin{array}{l}0.032 * * \\
(1.990)\end{array}$ & $\begin{array}{l}0.032^{* *} \\
(1.990)\end{array}$ & $\begin{array}{l}0.032 * * \\
(1.990)\end{array}$ \\
\hline L3D.Less severe actions & $\begin{array}{c}0.060^{* * *} \\
(3.338)\end{array}$ & $\begin{array}{c}0.060^{* * * *} \\
(3.338)\end{array}$ & $\begin{array}{c}0.060 * * * \\
(3.339)\end{array}$ \\
\hline LD.Severe actions & $\begin{array}{c}0.590 * * * \\
(44.219)\end{array}$ & $\begin{array}{l}0.590 * * * \\
(44.219)\end{array}$ & $\begin{array}{l}0.591 * * * \\
(44.230)\end{array}$ \\
\hline Year FE & Yes & Yes & Yes \\
\hline County FE & Yes & Yes & Yes \\
\hline Observations & 9,435 & 9,435 & 9,429 \\
\hline$R$-squared & 0.366 & 0.366 & 0.367 \\
\hline Counties & 1,891 & 1,891 & 1,891 \\
\hline Number of actions & 798 & 798 & 796 \\
\hline \multicolumn{4}{|c|}{ Panel C: IV regressions - Second stage } \\
\hline Dependent variable & Personal income growth & \# of Establishments & Unemployment rate \\
\hline L.Severe actions & $\begin{array}{c}-0.007 * * * \\
(-2.980)\end{array}$ & $\begin{array}{c}-0.017 \text { ** } \\
(-2.501)\end{array}$ & $\begin{array}{l}0.157^{*} \\
(1.792)\end{array}$ \\
\hline L.ln(Z-score) & $\begin{array}{c}0.002 * * * \\
(4.781)\end{array}$ & $\begin{array}{c}0.004 \\
(1.393)\end{array}$ & $\begin{array}{l}-0.124 * * * \\
(-4.545)\end{array}$ \\
\hline L.ln(HHI) & $\begin{array}{c}0.005 \\
(1.577)\end{array}$ & $\begin{array}{c}0.040 * * * \\
(2.989)\end{array}$ & $\begin{array}{c}-0.198 \\
(-1.148)\end{array}$ \\
\hline L.ln(Firm size) & $\begin{array}{c}0.007^{* * *} \\
(3.348)\end{array}$ & $\begin{array}{c}0.031 * * * \\
(5.142)\end{array}$ & $\begin{array}{l}-0.589 * * * \\
(-7.984)\end{array}$ \\
\hline Year FE & Yes & Yes & Yes \\
\hline County FE & Yes & Yes & Yes \\
\hline Observations & 9,435 & 9,435 & 9,429 \\
\hline$R$-squared & 0.035 & 0.344 & 0.720 \\
\hline Counties & 1,891 & 1,891 & 1,891 \\
\hline Number of actions & 798 & 798 & 796 \\
\hline Under-identification & 282.7 & 282.7 & 282.9 \\
\hline Weak-identification & 499.6 & 499.6 & 499.9 \\
\hline Hansen $J$-test & 1.032 & 1.933 & 2.269 \\
\hline$p$-value (Hansen) & 0.794 & 0.586 & 0.518 \\
\hline$C$-test (p-values) & & & \\
\hline LD.Less Severe actions & 0.9960 & 0.1799 & 0.2676 \\
\hline L2D.Less Severe actions & 0.3778 & 0.9797 & 0.4245 \\
\hline L3D.Less Severe actions & 0.6142 & 0.5890 & 0.1704 \\
\hline LD.Severe actions & 0.5677 & 0.2270 & 0.4043 \\
\hline $\begin{array}{l}\text { Notes. This table presents } \\
\text { number of establishments } \\
\text { show the first-stage and sc } \\
\text { Formal agreements, Ceas } \\
\text { one if enforcement actiol } \\
\text { soundness in the local ban } \\
\text { Herfindahl-Hirschman Inc } \\
\text { clustered on the county le } \\
* * p<0.05, * p<0.1 \text {. }\end{array}$ & $\begin{array}{l}\text { ariable regressions of enforce } \\
t \text { rate, all measured at the col } \\
\text { ectively, for the IV regression } \\
\text { r Prompt corrective action is } \\
\text { d individuals, and other Civi } \\
\text { ted by the Z-score (In), conce } \\
\text { firm size in the county (Firm } \\
\text { statistics are reported in parent }\end{array}$ & $\begin{array}{l}\text { in single-market banks on } \\
\text { nel A presents the OLS r } \\
\text { tt actions include Severe } \\
\text { zero otherwise); Less sev } \\
\text { s are observed, or zero } \\
\text { local banking market, } \mathrm{m} \\
\text { are and South Dakota cou } \\
\text { ial crisis years (2000-200 }\end{array}$ & $\begin{array}{l}\text { ersonal income growth, } \\
\text { while Panel B and Panel } \\
\text { 1my variable equal to one } \\
\text { a dummy variable equal } \\
\text { Dur regressions control } \\
\text { county-level deposit-bas } \\
\text { led. The standard errors } \\
\text { 2009) excluded. }{ }^{* * *} \text { p }<0\end{array}$ \\
\hline
\end{tabular}


Table 4

Main results: The macroeconomic effects of different types of enforcement actions

\begin{tabular}{|c|c|c|c|c|c|c|c|c|c|}
\hline \multicolumn{10}{|l|}{ Panel A: OLS regressions } \\
\hline Dependent variable & \multicolumn{3}{|c|}{ Personal income growth } & \multicolumn{3}{|c|}{ \# of Establishments } & \multicolumn{3}{|c|}{ Unemployment rate } \\
\hline L.Formal agreements & $\begin{array}{l}-0.006^{* *} \\
(-2.458)\end{array}$ & & & $\begin{array}{c}-0.018 * * * \\
(-2.739)\end{array}$ & & & $\begin{array}{c}0.127 \\
(1.199)\end{array}$ & & \\
\hline L. PCA & & $\begin{array}{l}-0.010^{*} \\
(-1.880)\end{array}$ & & & $\begin{array}{c}0.002 \\
(0.090)\end{array}$ & & & $\begin{array}{c}0.139 \\
(0.393)\end{array}$ & \\
\hline L.Cease \& desist orders & & & $\begin{array}{c}-0.005 * * * \\
(-3.338)\end{array}$ & & & $\begin{array}{c}-0.019 * * * \\
(-2.756)\end{array}$ & & & $\begin{array}{c}0.279 * * * \\
(3.237)\end{array}$ \\
\hline Controls, Year and County FE & Yes & Yes & Yes & Yes & Yes & Yes & Yes & Yes & Yes \\
\hline Observations & 9,435 & 9,435 & 9,435 & 9,435 & 9,435 & 9,435 & 9,429 & 9,429 & 9,429 \\
\hline$R$-squared & 0.035 & 0.034 & 0.035 & 0.343 & 0.343 & 0.344 & 0.719 & 0.719 & 0.720 \\
\hline Number of counties & 1,891 & 1,891 & 1,891 & 1,891 & 1,891 & 1,891 & 1,891 & 1,891 & 1,891 \\
\hline \multicolumn{10}{|c|}{ Panel B: First stage of IV regressions } \\
\hline Dependent variable & $\begin{array}{c}\text { L.Formal } \\
\text { Agreements }\end{array}$ & L.PCA & $\begin{array}{c}\text { L.Cease \& desist } \\
\text { orders }\end{array}$ & $\begin{array}{c}\text { L.Formal } \\
\text { Agreements }\end{array}$ & L.PCA & $\begin{array}{c}\text { L.Cease \& desist } \\
\text { orders }\end{array}$ & $\begin{array}{c}\text { L.Formal } \\
\text { Agreements }\end{array}$ & L.PCA & $\begin{array}{c}\text { L.Cease \& desist } \\
\text { orders }\end{array}$ \\
\hline LD.Less Severe actions & $\begin{array}{l}0.021^{*} \\
(1.681)\end{array}$ & $\begin{array}{l}0.010^{*} \\
(1.686)\end{array}$ & $\begin{array}{c}0.042 * * * \\
(2.623)\end{array}$ & $\begin{array}{l}0.021 * \\
(1.681)\end{array}$ & $\begin{array}{l}0.010^{*} \\
(1.686)\end{array}$ & $\begin{array}{c}0.042 * * * \\
(2.623)\end{array}$ & $\begin{array}{l}0.021^{*} \\
(1.681)\end{array}$ & $\begin{array}{l}0.010^{*} \\
(1.686)\end{array}$ & $\begin{array}{c}0.042 * * * * \\
(2.623)\end{array}$ \\
\hline L2D.Less severe actions & $\begin{array}{c}0.010 \\
(0.810)\end{array}$ & $\begin{array}{c}0.003 \\
(1.119)\end{array}$ & $\begin{array}{l}0.027^{*} \\
(1.932)\end{array}$ & $\begin{array}{c}0.010 \\
(0.810)\end{array}$ & $\begin{array}{c}0.003 \\
(1.119)\end{array}$ & $\begin{array}{l}0.027 * \\
(1.932)\end{array}$ & $\begin{array}{c}0.010 \\
(0.810)\end{array}$ & $\begin{array}{c}0.003 \\
(1.119)\end{array}$ & $\begin{array}{l}0.027^{*} \\
(1.932)\end{array}$ \\
\hline L3D.Less severe actions & $\begin{array}{l}0.036 * * \\
(2.365)\end{array}$ & $\begin{array}{c}0.009 \\
(1.437)\end{array}$ & $\begin{array}{c}0.044 * * * * \\
(2.635)\end{array}$ & $\begin{array}{l}0.036 * * \\
(2.365)\end{array}$ & $\begin{array}{c}0.009 \\
(1.437)\end{array}$ & $\begin{array}{c}0.044 * * * * \\
(2.635)\end{array}$ & $\begin{array}{l}0.036^{* *} \\
(2.365)\end{array}$ & $\begin{array}{c}0.009 \\
(1.437)\end{array}$ & $\begin{array}{c}0.044 * * * \\
(2.636)\end{array}$ \\
\hline LD.Severe actions & $\begin{array}{l}0.266^{* * * *} \\
(14.408)\end{array}$ & $\begin{array}{l}0.010^{*} \\
(1.911)\end{array}$ & $\begin{array}{l}0.330 * * * \\
(17.137)\end{array}$ & $\begin{array}{l}0.266^{* * * *} \\
(14.408)\end{array}$ & $\begin{array}{l}0.010^{*} \\
(1.911)\end{array}$ & $\begin{array}{l}0.330 * * * \\
(17.137)\end{array}$ & $\begin{array}{l}0.266^{* * * *} \\
(14.413)\end{array}$ & $\begin{array}{l}0.010^{*} \\
(1.911)\end{array}$ & $\begin{array}{l}0.331 * * * \\
(17.146)\end{array}$ \\
\hline Controls, Year and County FE & Yes & Yes & Yes & Yes & Yes & Yes & Yes & Yes & Yes \\
\hline Observations & 9,435 & 9,435 & 9,435 & 9,435 & 9,435 & 9,435 & 9,429 & 9,429 & 9,429 \\
\hline$R$-squared & 0.143 & 0.015 & 0.197 & 0.143 & 0.015 & 0.197 & 0.143 & 0.015 & 0.198 \\
\hline Number of counties & 1,891 & 1,891 & 1,891 & 1,891 & 1,891 & 1,891 & 1,891 & 1,891 & 1,891 \\
\hline \multicolumn{10}{|c|}{ Panel C: Second stage of IV regressions } \\
\hline Dependent variable & \multicolumn{3}{|c|}{ Personal income growth } & \multicolumn{3}{|c|}{ \# of Establishments } & \multicolumn{3}{|c|}{ Unemployment rate } \\
\hline L.Formal agreements & $\begin{array}{c}-0.016 * * * \\
(-2.935)\end{array}$ & & & $\begin{array}{l}-0.037^{* *} \\
(-2.468)\end{array}$ & & & $\begin{array}{l}0.363 * \\
(1.838)\end{array}$ & & \\
\hline L. PCA & & $\begin{array}{l}-0.265^{*} \\
(-1.892)\end{array}$ & & & $\begin{array}{c}-0.260 \\
(-0.907)\end{array}$ & & & $\begin{array}{l}7.708 * \\
(1.741)\end{array}$ & \\
\hline L.Cease and desist order & & & $\begin{array}{c}-0.013 * * * \\
(-2.950)\end{array}$ & & & $\begin{array}{c}-0.029 * * \\
(-2.396)\end{array}$ & & & $\begin{array}{l}0.285^{*} \\
(1.838)\end{array}$ \\
\hline Controls, Year and County FE & Yes & Yes & Yes & Yes & Yes & Yes & Yes & Yes & Yes \\
\hline Observations & 9,435 & 9,435 & 9,435 & 9,435 & 9,435 & 9,435 & 9,429 & 9,429 & 9,429 \\
\hline$R$-squared & 0.033 & -0.103 & 0.033 & 0.343 & 0.326 & 0.344 & 0.719 & 0.673 & 0.720 \\
\hline Number of counties & 1,891 & 1,891 & 1,891 & 1,891 & 1,891 & 1,891 & 1,891 & 1,891 & 1,891 \\
\hline Under-identification & 130.8 & 7.119 & 158.1 & 130.8 & 7.119 & 158.1 & 130.8 & 7.119 & 158.4 \\
\hline Weak-identification & 52.74 & 1.796 & 76.47 & 52.74 & 1.796 & 76.47 & 52.77 & 1.796 & 76.56 \\
\hline Hansen $J$-test & 1.070 & 2.193 & 0.941 & 2.059 & 5.715 & 2.272 & 2.045 & 0.355 & 2.080 \\
\hline$p$-value (Hansen) & 0.784 & 0.533 & 0.816 & 0.560 & 0.126 & 0.518 & 0.563 & 0.949 & 0.556 \\
\hline$C$-test (p-values) & & & & & & & & & \\
\hline LD.Less Severe actions & 0.9871 & 0.1835 & 0.8750 & 0.1594 & 0.0246 & 0.1474 & 0.2815 & 0.7086 & 0.3130 \\
\hline L2D.Less Severe actions & 0.3509 & 0.5661 & 0.4290 & 0.9057 & 0.8463 & 0.9881 & 0.4659 & 0.7603 & 0.4187 \\
\hline L3D.Less Severe actions & 0.6645 & 0.7569 & 0.6824 & 0.5204 & 0.4294 & 0.5528 & 0.1938 & 0.7249 & 0.1843 \\
\hline LD. Severe actions & 0.6367 & 0.2638 & 0.7364 & 0.2006 & 0.0191 & 0.1636 & 0.2195 & 0.8273 & 0.4379 \\
\hline
\end{tabular}

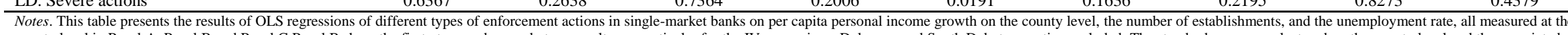

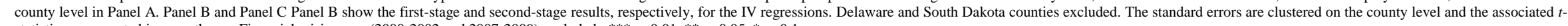
statistics are reported in parentheses. Financial crisis years (2000-2002 and 2007-2009) excluded. $* * * \mathrm{p}<0.01, * * \mathrm{*}<0.05,{ }^{*} \mathrm{p}<0.1$. 
Table 5

The macroeconomic effects of enforcement actions (multi-market banks included)

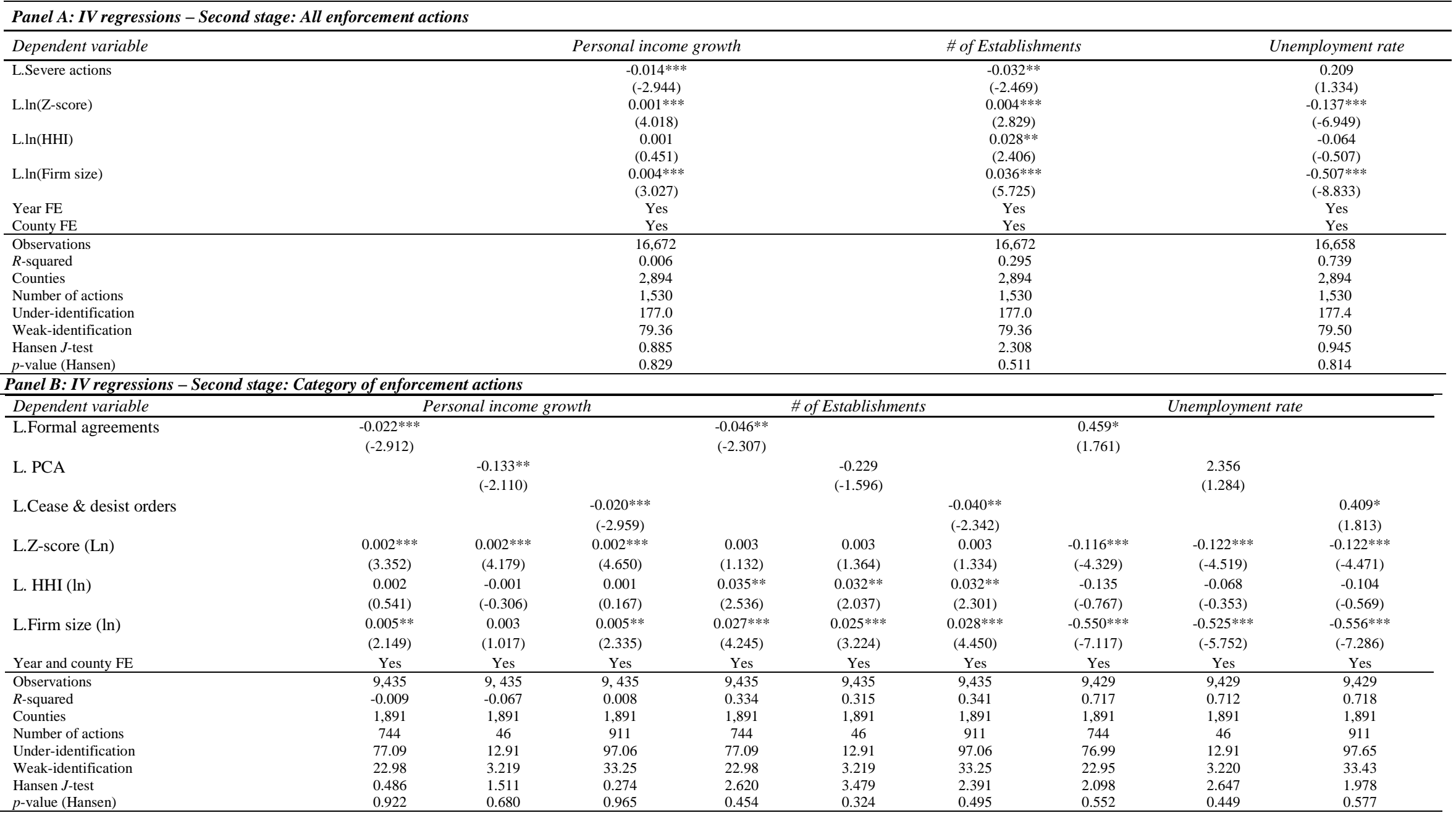

Notes. This table presents results of instrumental variable regressions of enforcement actions in single-market and multi-market banks on per capita personal income growth, the number of establishments, and the unemployment rate, all measured at the county level. Panel A presents the regressions considering any type of Severe actions (dummy variable equal to one if Formal agreements, Cease and desist order, and/or Prompt corrective action is observed and zero otherwise); Panel B presents the regressions considering the three types of Severe actions separately. Less severe action is a dummy variable equal to one if enforcement actions against Personnel and individuals, and other Civil money fines are observed, or zero otherwise). Our regressions control for soundness in the local banking market, approximated by the Z-score (ln), concentration of the local banking market, measured by a county-level deposit-based HerfindahlHirschman Index (HHI), and average firm size in the county (Firm size). Delaware and South Dakota counties excluded. The standard errors are clustered on the county level and the associated $t$-statistics are reported in parentheses. 
Table 6

Crisis episodes: The macroeconomic effects of supervisory enforcement actions: 2000-2002 and 2007-2009

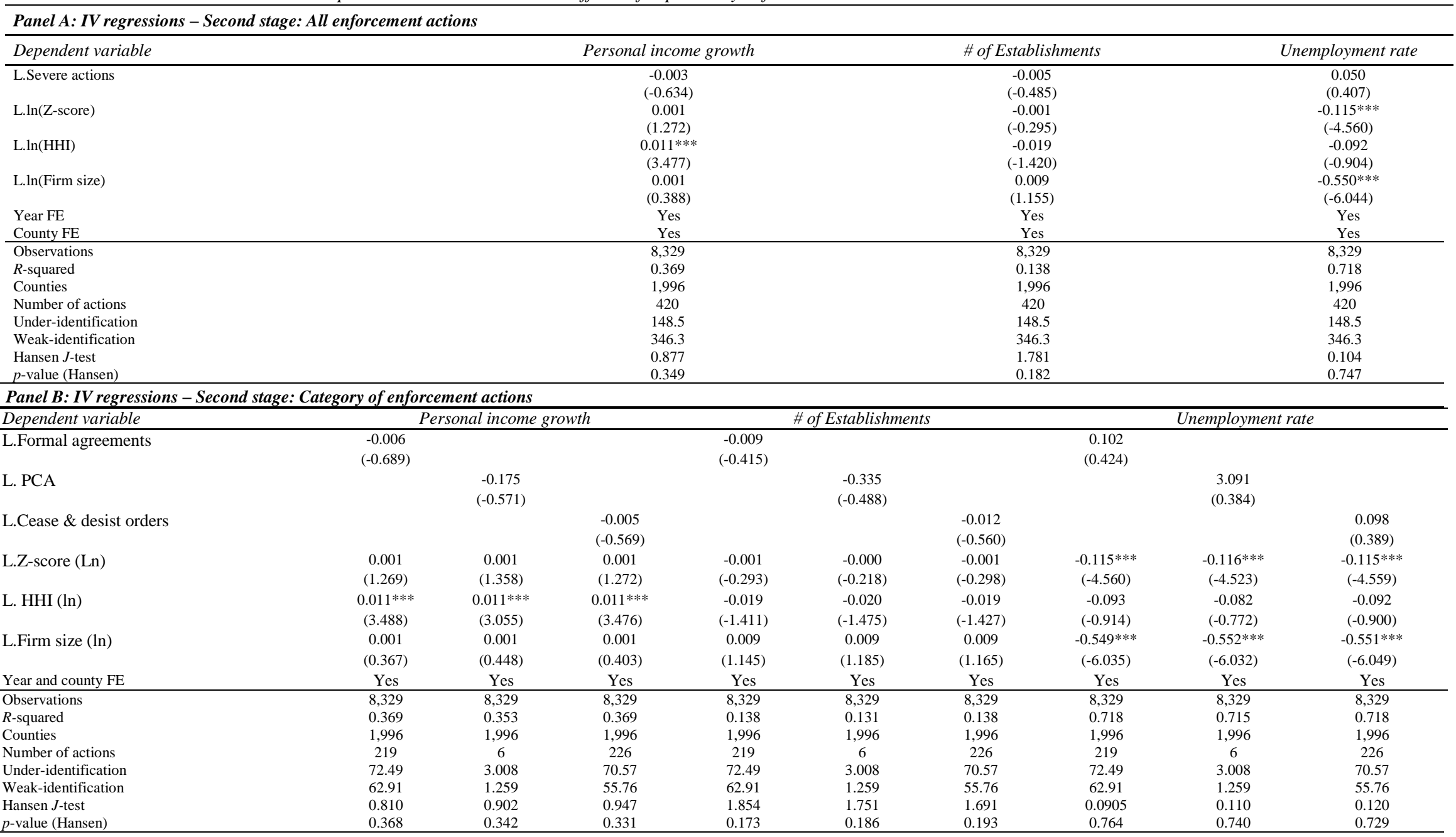

Notes. This table presents results of instrumental variable regressions of enforcement actions in single-market banks on per capita personal income growth, the number of establishments, and the unemployment rate, all measured at the county level. Panel A presents the regressions considering any type of Severe actions (dummy variable equal to one if Formal agreements, Cease and desist order, and/or Prompt corrective action is observed and zero otherwise); Panel B presents the regressions considering the the local banking market, approximated by the Z-score (In), concentration of the local banking market, measured by a county-level deposit-based Herfindahl-Hirschman Index (HHI), and average firm size in the county (Firm size). Delaware and South Dakota counties excluded. The standard errors are clustered on the county level and the associated $t$-statistics are reported in parentheses. *** $\mathrm{p}<0.01, * * \mathrm{p}<0.05, * \mathrm{p}<0.1$. 
Table 7

Mechanism: The effects of enforcement actions on bank lending and liquidity creation

\begin{tabular}{|c|c|c|c|c|c|c|c|c|c|}
\hline \multicolumn{10}{|c|}{ Panel A: First stage } \\
\hline & \multicolumn{5}{|c|}{ Bank lending } & \multicolumn{4}{|c|}{ Bank liquidity creation } \\
\hline Dependent variable: & $\begin{array}{l}\text { L.Severe } \\
\text { actions }\end{array}$ & $\begin{array}{c}\text { L.Severe } \\
\text { actions }\end{array}$ & $\begin{array}{l}\text { L.Severe } \\
\text { actions }\end{array}$ & $\begin{array}{l}\text { L.Severe } \\
\text { actions }\end{array}$ & $\begin{array}{l}\text { L.Severe } \\
\text { actions }\end{array}$ & $\begin{array}{c}\text { L.Severe } \\
\text { actions }\end{array}$ & $\begin{array}{l}\text { L.Severe } \\
\text { actions }\end{array}$ & $\begin{array}{c}\text { L.Severe } \\
\text { actions }\end{array}$ & $\begin{array}{c}\text { L.Severe } \\
\text { actions }\end{array}$ \\
\hline LD.Less severe actions & $\begin{array}{c}0.033 * * * \\
(2.676)\end{array}$ & $\begin{array}{c}0.033 * * * \\
(2.676)\end{array}$ & $\begin{array}{c}0.033 * * * \\
(2.676)\end{array}$ & $\begin{array}{c}0.033 * * * \\
(2.676)\end{array}$ & $\begin{array}{c}0.033^{* * * *} \\
(2.676)\end{array}$ & $\begin{array}{c}0.033 * * * * \\
(2.676)\end{array}$ & $\begin{array}{c}0.033 * * * * \\
(2.676)\end{array}$ & $\begin{array}{c}0.033 * * * \\
(2.676)\end{array}$ & $\begin{array}{c}0.033^{* * * *} \\
(2.676)\end{array}$ \\
\hline L2D.Less severe actions & $\begin{array}{c}0.035^{* * * *} \\
(2.739)\end{array}$ & $\begin{array}{c}0.035^{* * * *} \\
(2.739)\end{array}$ & $\begin{array}{c}0.035^{* * * *} \\
(2.739)\end{array}$ & $\begin{array}{c}0.035 * * * \\
(2.739)\end{array}$ & $\begin{array}{c}0.035 * * * \\
(2.739)\end{array}$ & $\begin{array}{c}0.035^{* * *} * \\
(2.739)\end{array}$ & $\begin{array}{c}0.035^{* * *} * \\
(2.739)\end{array}$ & $\begin{array}{c}0.035^{* * * *} \\
(2.739)\end{array}$ & $\begin{array}{c}0.035^{* * *} \\
(2.739)\end{array}$ \\
\hline L3D.Less severe actions & $\begin{array}{c}0.045 * * * \\
(3.258)\end{array}$ & $\begin{array}{c}0.045 * * * \\
(3.258)\end{array}$ & $\begin{array}{c}0.045 * * * \\
(3.258)\end{array}$ & $\begin{array}{c}0.045^{* * *} \\
(3.258)\end{array}$ & $\begin{array}{c}0.045^{* * * *} \\
(3.258)\end{array}$ & $\begin{array}{c}0.045^{* * * *} \\
(3.258)\end{array}$ & $\begin{array}{c}0.045^{* * * *} \\
(3.258)\end{array}$ & $\begin{array}{c}0.045^{* * * *} \\
(3.258)\end{array}$ & $\begin{array}{c}0.045^{* * * *} \\
(3.258)\end{array}$ \\
\hline LD.Severe actions & $\begin{array}{c}0.625^{* * * *} \\
(40.919)\end{array}$ & $\begin{array}{c}0.625^{* * * *} \\
(40.919)\end{array}$ & $\begin{array}{c}0.625 * * * \\
(40.919)\end{array}$ & $\begin{array}{c}0.625^{* * * *} \\
(40.919)\end{array}$ & $\begin{array}{c}0.625^{* * *} \\
(40.919)\end{array}$ & $\begin{array}{c}0.625 * * * \\
(40.919)\end{array}$ & $\begin{array}{c}0.625 * * * \\
(40.919)\end{array}$ & $\begin{array}{c}0.625^{* * * *} \\
(40.919)\end{array}$ & $\begin{array}{c}0.625^{* * * *} \\
(40.919)\end{array}$ \\
\hline Controls & Yes & Yes & Yes & Yes & Yes & Yes & Yes & Yes & Yes \\
\hline Year FE & Yes & Yes & Yes & Yes & Yes & Yes & Yes & Yes & Yes \\
\hline Bank FE & Yes & Yes & Yes & Yes & Yes & Yes & Yes & Yes & Yes \\
\hline$R$-squared & 0.397 & 0.397 & 0.397 & 0.397 & 0.397 & 0.397 & 0.397 & 0.397 & 0.397 \\
\hline \multicolumn{10}{|c|}{$\begin{array}{l}\text { Panel B: Second stage } \\
\end{array}$} \\
\hline Dependent variable & $\begin{array}{l}\text { Total lending } \\
\text { growth }\end{array}$ & $\begin{array}{c}\text { Corporate real } \\
\text { estate loan } \\
\text { growth }\end{array}$ & $\begin{array}{l}\text { Residential real } \\
\text { estate loan } \\
\text { growth }\end{array}$ & $\begin{array}{l}\text { Commercial } \\
\text { and industrial } \\
\text { loan growth }\end{array}$ & $\begin{array}{c}\text { Consumer loan } \\
\text { growth }\end{array}$ & $\begin{array}{c}\text { Liquidity } \\
\text { creation growth }\end{array}$ & $\begin{array}{c}\text { Liquidity } \\
\text { creation growth } \\
\text { (asset side) }\end{array}$ & $\begin{array}{c}\text { Liquidity } \\
\text { creation growth } \\
\text { (liability side) }\end{array}$ & $\begin{array}{l}\text { Liquidity creation } \\
\text { growth (off } \\
\text { balance) }\end{array}$ \\
\hline L.Severe actions & $\begin{array}{c}-0.083 * * * \\
(-4.590)\end{array}$ & $\begin{array}{l}-0.066^{*} \\
(-1.804)\end{array}$ & $\begin{array}{c}-0.039 \\
(-1.519)\end{array}$ & $\begin{array}{c}-0.102 * * * \\
(-3.319)\end{array}$ & $\begin{array}{c}-0.080^{* * * *} \\
(-2.601)\end{array}$ & $\begin{array}{c}-0.121 * * * \\
(-3.222)\end{array}$ & $\begin{array}{c}-0.268 * * \\
(-2.294)\end{array}$ & $\begin{array}{c}-0.066 * * * \\
(-2.795)\end{array}$ & $\begin{array}{c}-0.045 \\
(-1.021)\end{array}$ \\
\hline L.ln(Z-score) & $\begin{array}{c}0.013 * * * \\
(8.107)\end{array}$ & $\begin{array}{l}0.006^{* * *} \\
(2.115)\end{array}$ & $\begin{array}{l}0.005^{* *} \\
(2.349)\end{array}$ & $\begin{array}{l}0.014 * * * \\
(5.343)\end{array}$ & $\begin{array}{c}0.007 * * * \\
(2.971)\end{array}$ & $\begin{array}{l}0.017 * * * \\
(5.974)\end{array}$ & $\begin{array}{c}0.030 * * * \\
(3.515)\end{array}$ & $\begin{array}{c}0.013 * * * \\
(6.934)\end{array}$ & $\begin{array}{c}0.019 * * * \\
(5.862)\end{array}$ \\
\hline L. $\ln (\mathrm{HHI})$ & $\begin{array}{c}0.013 \\
(1.278)\end{array}$ & $\begin{array}{c}0.003 \\
(0.161)\end{array}$ & $\begin{array}{c}0.007 \\
(0.482)\end{array}$ & $\begin{array}{c}0.022 \\
(1.286)\end{array}$ & $\begin{array}{c}-0.022 \\
(-1.449)\end{array}$ & $\begin{array}{l}0.036^{*} \\
(1.906)\end{array}$ & $\begin{array}{c}-0.010 \\
(-0.159)\end{array}$ & $\begin{array}{c}0.017 \\
(1.434)\end{array}$ & $\begin{array}{c}0.057 * * * \\
(2.767)\end{array}$ \\
\hline L.ln(Firm Size $)$ & $\begin{array}{l}0.009^{*} \\
(1.876)\end{array}$ & $\begin{array}{l}0.005 \\
(0.394)\end{array}$ & $\begin{array}{c}0.005 \\
(0.803)\end{array}$ & $\begin{array}{l}-0.009 \\
(-0.940)\end{array}$ & $\begin{array}{l}-0.007 \\
(-1.037)\end{array}$ & $\begin{array}{c}0.002 \\
(0.189)\end{array}$ & $\begin{array}{l}-0.029 \\
(-0.749)\end{array}$ & $\begin{array}{c}0.009 \\
(1.535)\end{array}$ & $\begin{array}{l}0.029 * * \\
(2.123)\end{array}$ \\
\hline Year FE & Yes & Yes & Yes & Yes & Yes & Yes & Yes & Yes & Yes \\
\hline Bank FE & Yes & Yes & Yes & Yes & Yes & Yes & Yes & Yes & Yes \\
\hline Observations & 33,678 & 33,678 & 33,678 & 33,678 & 33,678 & 33,678 & 33,678 & 33,678 & 33,678 \\
\hline$R$-squared & 0.039 & 0.018 & 0.015 & 0.012 & 0.010 & 0.019 & 0.004 & 0.081 & 0.029 \\
\hline Banks & 7,025 & 7,025 & 7,025 & 7,025 & 7,025 & 7,025 & 7,025 & 7,025 & 7,025 \\
\hline Number of actions & 892 & 892 & 892 & 892 & 892 & 892 & 892 & 892 & 892 \\
\hline Under-identification & 295.1 & 295.1 & 295.1 & 295.1 & 295.1 & 295.1 & 295.1 & 295.1 & 295.1 \\
\hline Weak-identification & 424.0 & 424.0 & 424.0 & 424.0 & 424.0 & 424.0 & 424.0 & 424.0 & 424.0 \\
\hline Hansen $J$-test & 2.512 & 3.618 & 0.470 & 6.532 & 0.582 & 5.977 & 4.346 & 2.169 & 5.825 \\
\hline$p$-value (Hansen) & 0.473 & 0.306 & 0.926 & 0.0884 & 0.901 & 0.113 & 0.226 & 0.538 & 0.120 \\
\hline
\end{tabular}

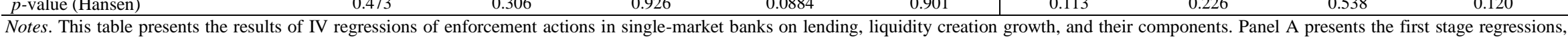
and Panel B shows the second stage results. The standard errors are clustered on the bank level and the associated $t$-statistics are reported in parentheses. Financial crisis years (2000-2002 and 2007-2009) excluded. $* * * \mathrm{p}<0.01, * * \mathrm{p}<0.05, * \mathrm{p}<0.1$ 
Table 8

Complementary evidence: Analyses conditioned on bank representation and external financial dependence

\begin{tabular}{|c|c|c|c|c|c|c|}
\hline \multicolumn{7}{|c|}{ Panel A: Bank representation } \\
\hline Dependent variable & \multicolumn{2}{|c|}{ Personal income growth } & \multicolumn{2}{|c|}{ \# of Establishments } & \multicolumn{2}{|c|}{ Unemployment rate } \\
\hline $\begin{array}{l}\text { Sample conditioned on } \\
\text { counties where }\end{array}$ & $\begin{array}{c}\text { bank } \\
\text { representation } \\
<p 25\end{array}$ & $\begin{array}{c}\text { bank } \\
\text { representation } \\
>p 75\end{array}$ & $\begin{array}{c}\text { bank } \\
\text { representation } \\
<p 25\end{array}$ & $\begin{array}{c}\text { bank } \\
\text { representation } \\
>\text { p } 75\end{array}$ & $\begin{array}{c}\text { bank } \\
\text { representation } \\
<p 25\end{array}$ & $\begin{array}{c}\text { bank } \\
\text { representation } \\
>p 75\end{array}$ \\
\hline L.Severe actions & $\begin{array}{c}-0.017 * * * \\
(-3.509)\end{array}$ & $\begin{array}{c}-0.001 \\
(-0.376)\end{array}$ & $\begin{array}{c}-0.031 * * \\
(-2.193)\end{array}$ & $\begin{array}{c}-0.007 \\
(-0.535)\end{array}$ & $\begin{array}{l}0.330^{*} \\
(1.706)\end{array}$ & $\begin{array}{c}0.004 \\
(0.030)\end{array}$ \\
\hline L.ln(Z-score) & $\begin{array}{c}0.002 * * * \\
(4.492)\end{array}$ & $\begin{array}{l}-0.003 \\
(-0.982)\end{array}$ & $\begin{array}{c}0.000 \\
(0.028)\end{array}$ & $\begin{array}{c}0.027 * * \\
(2.264)\end{array}$ & $\begin{array}{c}-0.083 * * * \\
(-4.899)\end{array}$ & $\begin{array}{c}-0.738 * * * \\
(-5.613)\end{array}$ \\
\hline L.ln(HHI) & $\begin{array}{c}0.001 \\
(0.200)\end{array}$ & $\begin{array}{c}-0.004 \\
(-0.747)\end{array}$ & $\begin{array}{c}0.024 \\
(0.876)\end{array}$ & $\begin{array}{c}0.000 \\
(0.020)\end{array}$ & $\begin{array}{c}-0.112 \\
(-0.479)\end{array}$ & $\begin{array}{c}0.059 \\
(0.099)\end{array}$ \\
\hline L.ln(Firm size) & $\begin{array}{c}0.003 \\
(1.179)\end{array}$ & $\begin{array}{c}0.008 \\
(0.768)\end{array}$ & $\begin{array}{l}0.021 * * \\
(2.568)\end{array}$ & $\begin{array}{c}0.001 \\
(0.035)\end{array}$ & $\begin{array}{c}-0.412 * * * \\
(-4.239)\end{array}$ & $\begin{array}{l}-0.654^{*} \\
(-1.860)\end{array}$ \\
\hline $\begin{array}{l}\text { Year FE } \\
\text { County FE }\end{array}$ & $\begin{array}{l}\text { Yes } \\
\text { Yes }\end{array}$ & $\begin{array}{l}\text { Yes } \\
\text { Yes }\end{array}$ & $\begin{array}{l}\text { Yes } \\
\text { Yes }\end{array}$ & $\begin{array}{l}\text { Yes } \\
\text { Yes }\end{array}$ & $\begin{array}{l}\text { Yes } \\
\text { Yes }\end{array}$ & $\begin{array}{l}\text { Yes } \\
\text { Yes }\end{array}$ \\
\hline Observations & 4,184 & 726 & 4,184 & 726 & 4,182 & 724 \\
\hline$R$-squared & 0.032 & 0.202 & 0.259 & 0.488 & 0.699 & 0.826 \\
\hline Counties & 918 & 154 & 918 & 154 & 918 & 154 \\
\hline Number of actions & 234 & 197 & 234 & 197 & 234 & 195 \\
\hline Under-identification & 79.99 & 50.22 & 79.99 & 50.22 & 79.99 & 50.56 \\
\hline Weak-identification & 106.6 & 84.08 & 106.6 & 84.08 & 106.6 & 84.26 \\
\hline Hansen $J$-test & 4.627 & 3.758 & 4.425 & 2.915 & 0.557 & 5.616 \\
\hline$p$-value (Hansen) & 0.201 & 0.289 & 0.219 & 0.405 & 0.906 & 0.132 \\
\hline \multicolumn{7}{|c|}{ Panel B: External financial dependence } \\
\hline Dependent variable & Personal i & me growth & \# of Est & ishments & Unempl & ment rate \\
\hline $\begin{array}{l}\text { Sample conditioned on } \\
\text { counties where }\end{array}$ & $\begin{array}{c}\text { external } \\
\text { financial } \\
\text { dependence } \\
<\text { p25 }\end{array}$ & $\begin{array}{c}\text { external } \\
\text { financial } \\
\text { dependence } \\
>\text { p75 }\end{array}$ & $\begin{array}{c}\text { external } \\
\text { financial } \\
\text { dependence } \\
<p 25\end{array}$ & $\begin{array}{c}\text { external } \\
\text { financial } \\
\text { dependence } \\
>\text { p } 75\end{array}$ & $\begin{array}{c}\text { external } \\
\text { financial } \\
\text { dependence }< \\
\text { p25 }\end{array}$ & $\begin{array}{c}\text { external } \\
\text { financial } \\
\text { dependence > } \\
\text { p75 }\end{array}$ \\
\hline L.Severe actions & $\begin{array}{c}-0.008 \\
(-1.326)\end{array}$ & $\begin{array}{c}-0.016 * * * \\
(-2.939)\end{array}$ & $\begin{array}{c}0.009 \\
(0.738)\end{array}$ & $\begin{array}{l}-0.027^{*} \\
(-1.882)\end{array}$ & $\begin{array}{l}0.350^{*} \\
(1.832)\end{array}$ & $\begin{array}{c}0.496 * * * \\
(2.583)\end{array}$ \\
\hline L.ln(Z-score) & $\begin{array}{c}-0.002 \\
(-0.961)\end{array}$ & $\begin{array}{c}0.002 * * * \\
(2.982)\end{array}$ & $\begin{array}{c}0.005 \\
(1.418)\end{array}$ & $\begin{array}{c}0.001 \\
(0.257)\end{array}$ & $\begin{array}{c}-0.217 * * * \\
(-3.196)\end{array}$ & $\begin{array}{l}-0.072 * \\
(-1.823)\end{array}$ \\
\hline L.ln(HHI) & $\begin{array}{c}-0.002 \\
(-0.307)\end{array}$ & $\begin{array}{c}0.005 \\
(0.792)\end{array}$ & $\begin{array}{l}-0.001 \\
(-0.023)\end{array}$ & $\begin{array}{l}0.088 * * * \\
(2.736)\end{array}$ & $\begin{array}{l}-0.618 \\
(-1.576)\end{array}$ & $\begin{array}{c}-0.837 * * * \\
(-3.615)\end{array}$ \\
\hline L.ln(Firm size) & $\begin{array}{l}-0.002 \\
(-0.706)\end{array}$ & $\begin{array}{l}0.015 * * \\
(2.551)\end{array}$ & $\begin{array}{l}0.019 * * \\
(2.524)\end{array}$ & $\begin{array}{c}0.047 * * * \\
(2.733)\end{array}$ & $\begin{array}{c}-0.087 \\
(-0.702)\end{array}$ & $\begin{array}{c}-0.826 * * * \\
(-4.934)\end{array}$ \\
\hline Year FE & Yes & Yes & Yes & Yes & Yes & Yes \\
\hline County FE & Yes & Yes & Yes & Yes & Yes & Yes \\
\hline Observations & 1,547 & 2,779 & 1,547 & 2,779 & 1,547 & 2,779 \\
\hline$R$-squared & 0.020 & 0.046 & 0.317 & 0.222 & 0.777 & 0.640 \\
\hline Counties & 369 & 611 & 369 & 611 & 369 & 611 \\
\hline Number of actions & 109 & 235 & 109 & 235 & 109 & 235 \\
\hline Under-identification & 47.95 & 81.26 & 47.95 & 81.26 & 47.95 & 81.26 \\
\hline Weak-identification & 83.77 & 117.2 & 83.77 & 117.2 & 83.77 & 117.2 \\
\hline Hansen $J$-test & 5.377 & 1.701 & 2.537 & 3.942 & 4.775 & 3.294 \\
\hline$p$-value (Hansen) & 0.146 & 0.637 & 0.469 & 0.268 & 0.189 & 0.348 \\
\hline
\end{tabular}

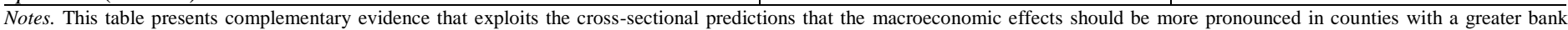

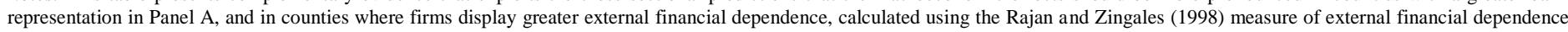

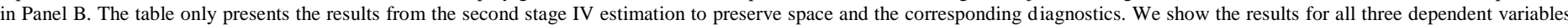

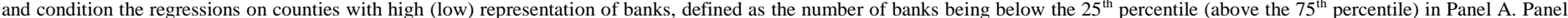

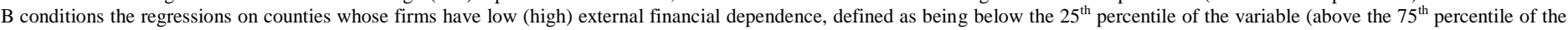

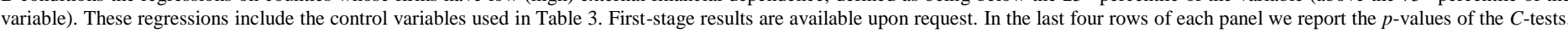

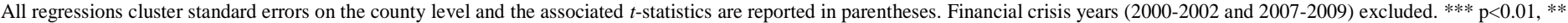
$\mathrm{p}<0.05, * \mathrm{p}<0.1$ 
Table 9

Long-run effects and the behavior of competitor institutions

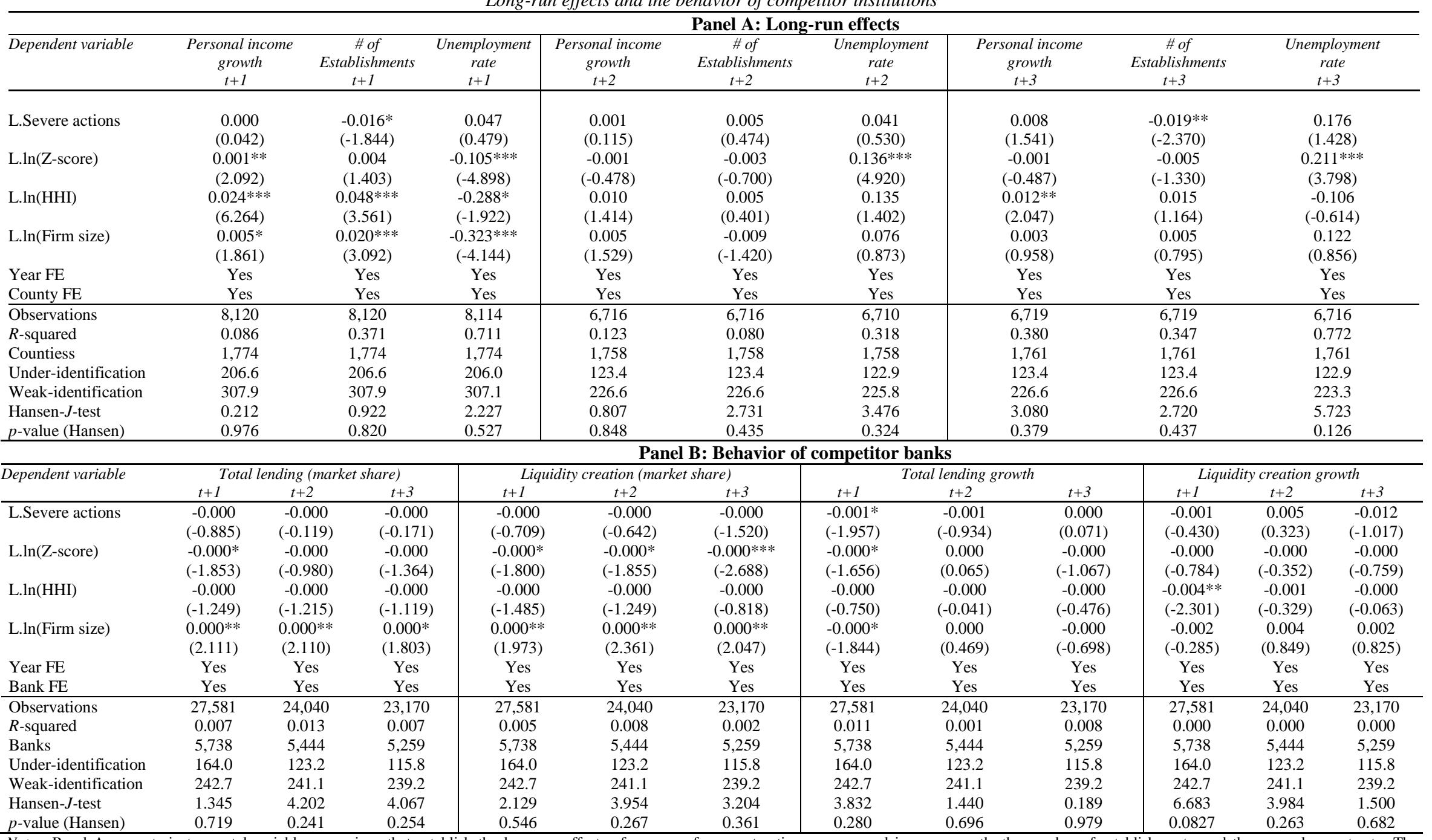

Notes. Panel A presents instrumental variable regressions that establish the long-run effects of severe enforcement actions on personal income growth, the number of establishments, and the unemployment rate. The dependent variables are forwarded one, two, and three years. Panel B examines the behavior of competitor banks' market shares in terms of total lending and liquidity creation, and the corresponding growth rates for one, two, and three years following the announcements of severe enforcement actions using instrumental variable regressions. The control variables discussed in the notes to Table 3 are included. We only show second-stage results. First-stage results are available upon request. The standard errors are clustered on the county and bank level for Panel A and Panel B, respectively, and the associated $t$-statistics are reported in parentheses. Financia crisis years (2000-2002 and 2007-2009) excluded. *** $\mathrm{p}<0.01, * * \mathrm{p}<0.05, * \mathrm{p}<0.1$. 


\section{Figure 1}

\section{Local banking markets in the U.S. (Development over time)}

Figure 1 presents the location and number of counties in which single-market banks operate, at the beginning and the end of the sample period (1999 and 2011). Counties shaded in dark blue represent counties in which all operating banks are single-market banks. Counties shaded in dark grey color are counties where at least one single-market is located. All other counties are shaded in light grey color.

\section{Development over time}

Local banking markets in U.S. counties

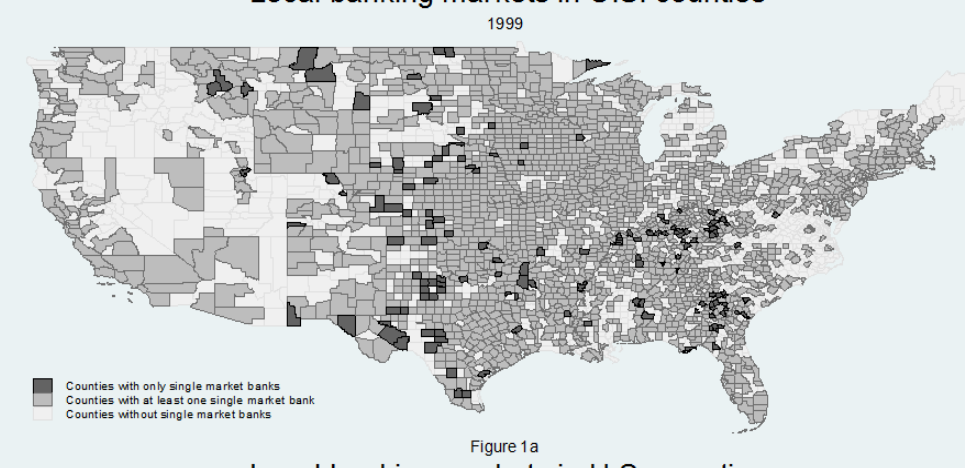

Local banking markets in U.S. counties

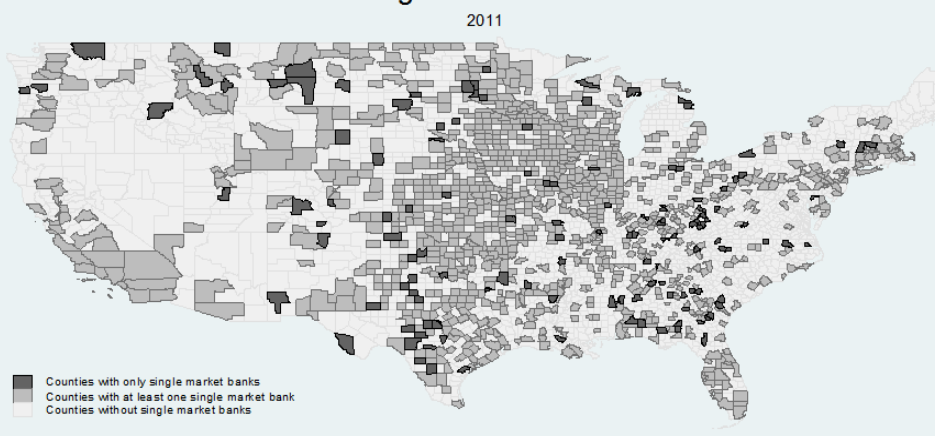

Figure 1b 


\section{Figure 2}

Enforcement actions in U.S. counties (Development over time)

Figure 2 presents the location and number of counties in which single-market banks were subject to enforcement actions. We present their location and number at the beginning and the end of the sample period (year 1999 and 2011). Counties shaded in red represent intervention counties. All other counties are shaded in light grey color.

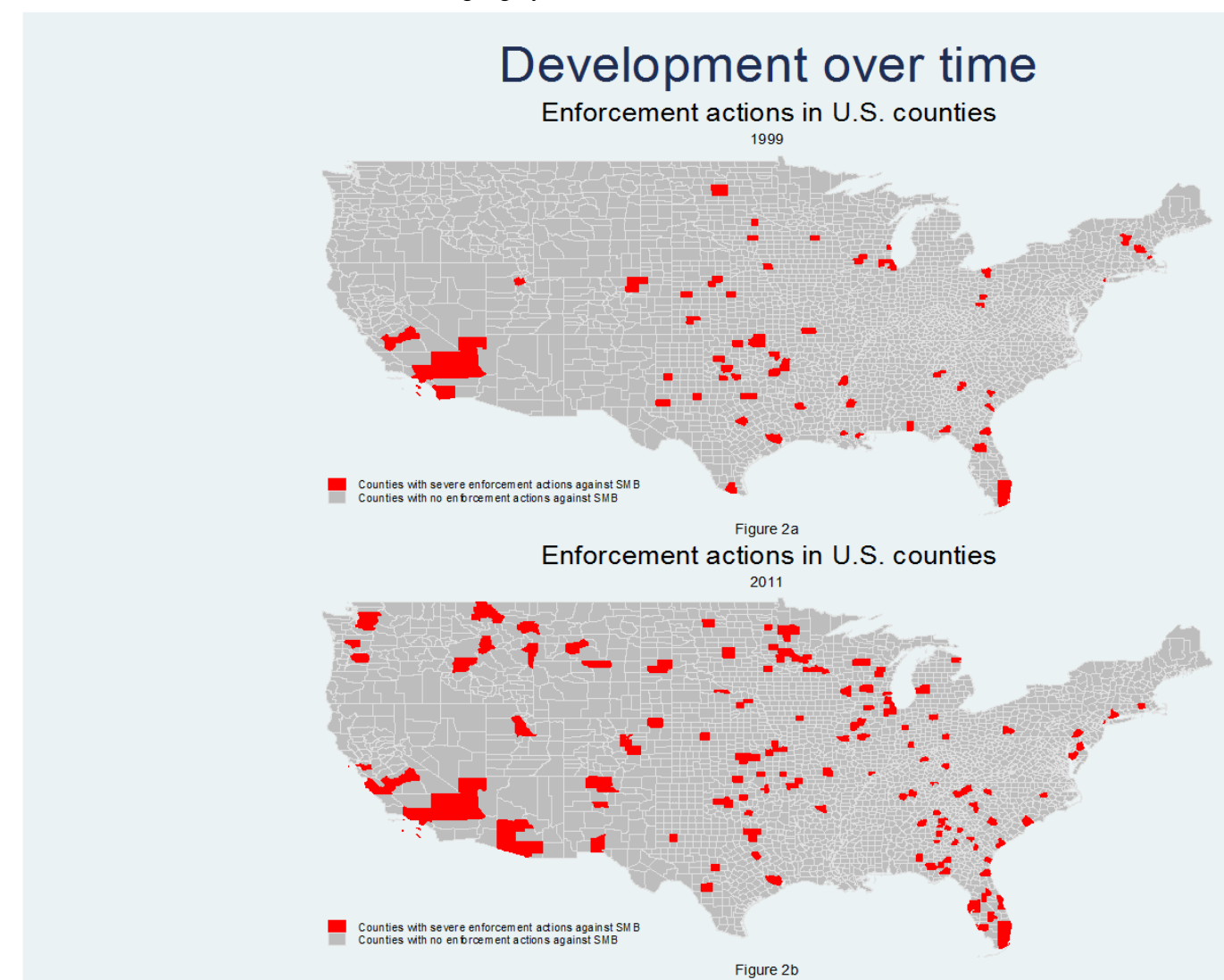

Source: SNL Financial, authors' calculations 


\section{Appendix}

\section{The real effects of banking supervision: Evidence from enforcement actions}




\section{Appendix}

The real effects of banking supervision: Evidence from enforcement actions

Table A.1 Relationship between less severe and severe enforcement actions

\begin{tabular}{|c|c|c|}
\hline Dependent variable & Less severe enforcement actions & Severe actions \\
\hline D.Severe actions & $\begin{array}{c}0.009 \\
(0.756)\end{array}$ & \\
\hline D.Less severe enforcement action & & $\begin{array}{l}0.035 * * * \\
(3.019)\end{array}$ \\
\hline Year FE & Yes & Yes \\
\hline Bank FE & Yes & Yes \\
\hline Observations & 38,558 & 38,558 \\
\hline$R$-squared & 0.002 & 0.016 \\
\hline Number of banks & 7,062 & 7,062 \\
\hline
\end{tabular}

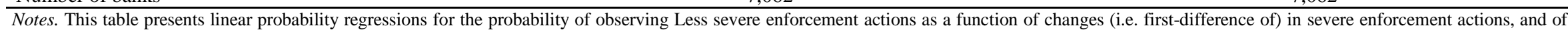

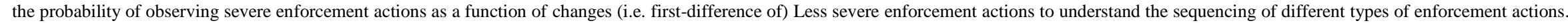

The standard errors are clustered on the bank level and the associated $t$-statistics are reported in parentheses. $* * * \mathrm{p}<0.01, * * \mathrm{p}<0.05, * \mathrm{p}<0.1$ 


\section{Appendix}

The real effects of banking supervision: Evidence from enforcement actions

Table A.2 Summary statistics for selected loan categories

\begin{tabular}{|c|c|c|c|c|}
\hline Year & Corporate real estate loans & Residential real estate loans & C\&I loans & Consumer loans \\
\hline & (\% of total loans) & (\% of total loans) & (\% of total loans) & (\% of total loans) \\
\hline 1999 & 0.156 & 0.308 & 0.162 & 0.147 \\
\hline 2000 & 0.166 & 0.303 & 0.166 & 0.139 \\
\hline 2001 & 0.173 & 0.303 & 0.166 & 0.133 \\
\hline 2002 & 0.184 & 0.298 & 0.162 & 0.124 \\
\hline 2003 & 0.199 & 0.295 & 0.157 & 0.114 \\
\hline 2004 & 0.212 & 0.287 & 0.154 & 0.105 \\
\hline 2005 & 0.217 & 0.284 & 0.151 & 0.095 \\
\hline 2006 & 0.221 & 0.275 & 0.149 & 0.088 \\
\hline 2007 & 0.222 & 0.267 & 0.149 & 0.082 \\
\hline 2008 & 0.223 & 0.261 & 0.150 & 0.078 \\
\hline 2009 & 0.237 & 0.268 & 0.146 & 0.072 \\
\hline 2010 & 0.252 & 0.277 & 0.139 & 0.070 \\
\hline 2011 & 0.260 & 0.281 & 0.137 & 0.067 \\
\hline Average & 0.208 & 0.286 & 0.153 & 0.102 \\
\hline
\end{tabular}

Notes. This table presents statistics for the distribution of lending. The different types of loans are scaled by total loans per year. 


\section{Appendix}

The real effects of banking supervision: Evidence from enforcement actions

Table A.3 Additional Robustness Test - Excluding banks which received TARP capital support

\begin{tabular}{|c|c|c|}
\hline Dependent variable & Total lending growth & Liquidity creation growth \\
\hline L.Severe actions & $\begin{array}{c}-0.080 * * * \\
(-4.447)\end{array}$ & $\begin{array}{c}-0.113^{* * *} \\
(-3.061)\end{array}$ \\
\hline L.ln(Z-score) & $\begin{array}{c}0.013 * * * \\
(8.148)\end{array}$ & $\begin{array}{l}0.017 * * * \\
(6.028)\end{array}$ \\
\hline L.ln(HHI) & $\begin{array}{c}0.013 \\
(1.247)\end{array}$ & $\begin{array}{l}0.037^{*} \\
(1.922)\end{array}$ \\
\hline L.ln(Firm Size $)$ & $\begin{array}{l}0.008^{*} \\
(1.773)\end{array}$ & $\begin{array}{c}0.002 \\
(0.168)\end{array}$ \\
\hline $\begin{array}{l}\text { Year FE } \\
\text { Bank FE }\end{array}$ & $\begin{array}{l}\text { Yes } \\
\text { Yes }\end{array}$ & $\begin{array}{l}\text { Yes } \\
\text { Yes }\end{array}$ \\
\hline Observations & 32,880 & 32,880 \\
\hline$R$-squared & 0.039 & 0.019 \\
\hline Number of banks & 6,262 & 6,262 \\
\hline Under-identification & 293.3 & 293.3 \\
\hline Weak-identification & 419.2 & 419.2 \\
\hline Hansen- $J$-test & 2.390 & 5.821 \\
\hline$p$-value (Hansen) & 0.495 & 0.121 \\
\hline
\end{tabular}

$\frac{p \text {-value (Hansen) }}{\text { Notes. This table presents additional results of instrumental variable regressions of enforcement actions on single-market banks. We exclude banks which received capital support from the Troubled Asset Relief }} 0.495$ Notes. This table presents additional results of instrumental variable regressions of enforcement actions on single-market banks. We exclude banks which received capital support from the Troubled Asset Relief
Programme. The explanatory variables are explained in the Notes to Table 3 . We only show the second-stage results. The standard errors are clustered on the bank level and the associated $t$-statistics are reported in parentheses. Financial crisis years (2000-2002 and 2007-2009) excluded. *** $\mathrm{p}<0.01, * * \mathrm{p}<0.05, * \mathrm{p}<0.1$. 


\section{Appendix}

The real effects of banking supervision: Evidence from enforcement actions

Table A.4 Mechanism: The effects of enforcement actions on bank lending and liquidity creation (multi-market banks included)

\begin{tabular}{|c|c|c|c|c|c|c|c|c|c|}
\hline \multicolumn{10}{|c|}{$\begin{array}{l}\text { Panel A: First stage } \\
\end{array}$} \\
\hline & \multicolumn{5}{|c|}{ Bank lending } & \multicolumn{4}{|c|}{ Bank liquidity creation } \\
\hline $\begin{array}{l}\text { Dependent variable: } \\
\text { L.Severe actions }\end{array}$ & $\begin{array}{l}\text { Total lending } \\
\text { growth }\end{array}$ & $\begin{array}{l}\text { Corporate real } \\
\text { estate loan } \\
\text { growth }\end{array}$ & $\begin{array}{l}\text { Residential real } \\
\text { estate loan } \\
\text { growth }\end{array}$ & $\begin{array}{l}\text { Commercial } \\
\text { and industrial } \\
\text { loan growth }\end{array}$ & $\begin{array}{l}\text { Consumer loan } \\
\text { growth }\end{array}$ & $\begin{array}{c}\text { Liquidity } \\
\text { creation growth }\end{array}$ & $\begin{array}{c}\text { Liquidity } \\
\text { creation growth } \\
\text { (asset side) }\end{array}$ & $\begin{array}{c}\text { Liquidity } \\
\text { creation growth } \\
\text { (liability side) }\end{array}$ & $\begin{array}{l}\text { Liquidity creation } \\
\text { growth (off } \\
\text { balance) }\end{array}$ \\
\hline LD.Less severe actions & $\begin{array}{c}0.029 * * \\
(2.227)\end{array}$ & $\begin{array}{c}0.029 * * \\
(2.227)\end{array}$ & $\begin{array}{c}0.029 * * \\
(2.227)\end{array}$ & $\begin{array}{c}0.029 * * \\
(2.227)\end{array}$ & $\begin{array}{c}0.029 * * \\
(2.227)\end{array}$ & $\begin{array}{c}0.029 * * \\
(2.227)\end{array}$ & $\begin{array}{c}0.029 * * \\
(2.227)\end{array}$ & $\begin{array}{c}0.029 * * \\
(2.227)\end{array}$ & $\begin{array}{c}0.029 * * \\
(2.227)\end{array}$ \\
\hline L2D.Less severe actions & $\begin{array}{c}0.036^{* * * *} \\
(2.810)\end{array}$ & $\begin{array}{c}0.036 * * * \\
(2.810)\end{array}$ & $\begin{array}{c}0.036 * * * \\
(2.810)\end{array}$ & $\begin{array}{c}0.036 * * * \\
(2.810)\end{array}$ & $\begin{array}{c}0.036 * * * \\
(2.810)\end{array}$ & $\begin{array}{c}0.036 * * * \\
(2.810)\end{array}$ & $\begin{array}{c}0.036 * * * \\
(2.810)\end{array}$ & $\begin{array}{c}0.036 * * * \\
(2.810)\end{array}$ & $\begin{array}{c}0.036 * * * \\
(2.810)\end{array}$ \\
\hline L3D.Less severe actions & $\begin{array}{c}0.036 * * \\
(2.559)\end{array}$ & $\begin{array}{c}0.036 * * \\
(2.559)\end{array}$ & $\begin{array}{c}0.036^{* * *} \\
(2.559)\end{array}$ & $\begin{array}{c}0.036 * * \\
(2.559)\end{array}$ & $\begin{array}{c}0.036 * * \\
(2.559)\end{array}$ & $\begin{array}{c}0.036 * * \\
(2.559)\end{array}$ & $\begin{array}{c}0.036 * * \\
(2.559)\end{array}$ & $\begin{array}{c}0.036 * * \\
(2.559)\end{array}$ & $\begin{array}{c}0.036 * * \\
(2.559)\end{array}$ \\
\hline LD.Severe actions & $\begin{array}{l}0.570 * * * \\
(32.838)\end{array}$ & $\begin{array}{l}0.570 * * * \\
(32.838)\end{array}$ & $\begin{array}{l}0.570 * * * \\
(32.838)\end{array}$ & $\begin{array}{l}0.570 * * * \\
(32.838)\end{array}$ & $\begin{array}{l}0.570 * * * \\
(32.838)\end{array}$ & $\begin{array}{l}0.570 * * * \\
(32.838)\end{array}$ & $\begin{array}{l}0.570 * * * \\
(32.838)\end{array}$ & $\begin{array}{l}0.570 * * * \\
(32.838)\end{array}$ & $\begin{array}{l}0.570 * * * \\
(32.838)\end{array}$ \\
\hline Controls & Yes & Yes & Yes & Yes & Yes & Yes & Yes & Yes & Yes \\
\hline Year FE & Yes & Yes & Yes & Yes & Yes & Yes & Yes & Yes & Yes \\
\hline Bank FE & Yes & Yes & Yes & Yes & Yes & Yes & Yes & Yes & Yes \\
\hline$R$-squared & 0.186 & 0.186 & 0.186 & 0.186 & 0.186 & 0.186 & 0.186 & 0.186 & 0.186 \\
\hline \multicolumn{10}{|c|}{ Panel B: Second stage } \\
\hline L.Severe actions & $\begin{array}{c}-0.092^{* * * *} \\
(-4.552)\end{array}$ & $\begin{array}{l}-0.080^{* *} \\
(-1.998)\end{array}$ & $\begin{array}{c}-0.044 \\
(-1.578)\end{array}$ & $\begin{array}{c}-0.109^{* * *} * \\
(-3.241)\end{array}$ & $\begin{array}{l}-0.080^{* * *} \\
(-2.410)\end{array}$ & $\begin{array}{l}-0.132^{* * * *} \\
(-3.235)\end{array}$ & $\begin{array}{c}-0.292 * * \\
(-2.334)\end{array}$ & $\begin{array}{l}-0.072 * * * \\
(-2.837)\end{array}$ & $\begin{array}{c}-0.053 \\
(-1.097)\end{array}$ \\
\hline L.ln(Z-score) & $\begin{array}{c}0.012 * * * \\
(8.102)\end{array}$ & $\begin{array}{l}0.005^{*} \\
(1.748)\end{array}$ & $\begin{array}{l}0.005 * * * \\
(2.587)\end{array}$ & $\begin{array}{c}0.013 * * * \\
(5.463)\end{array}$ & $\begin{array}{c}0.006 * * * \\
(2.945)\end{array}$ & $\begin{array}{c}0.016 * * * \\
(5.766)\end{array}$ & $\begin{array}{c}0.028 * * * \\
(3.409)\end{array}$ & $\begin{array}{c}0.011 * * * \\
(6.377)\end{array}$ & $\begin{array}{c}0.018 * * * \\
(5.989)\end{array}$ \\
\hline L. $\ln (\mathrm{HHI})$ & $\begin{array}{c}0.004 \\
(0.481)\end{array}$ & $\begin{array}{c}-0.009 \\
(-0.528)\end{array}$ & $\begin{array}{c}0.000 \\
(0.022)\end{array}$ & $\begin{array}{c}0.012 \\
(0.773)\end{array}$ & $\begin{array}{l}-0.021 \\
(-1.528)\end{array}$ & $\begin{array}{l}0.027 * \\
(1.655)\end{array}$ & $\begin{array}{c}0.012 \\
(0.223)\end{array}$ & $\begin{array}{l}0.011 \\
(1.097)\end{array}$ & $\begin{array}{c}0.049 * * * \\
(2.678)\end{array}$ \\
\hline L.ln(Firm Size) & $\begin{array}{c}0.004 \\
(0.930)\end{array}$ & $\begin{array}{c}-0.000 \\
(-0.025)\end{array}$ & $\begin{array}{c}-0.002 \\
(-0.329)\end{array}$ & $\begin{array}{c}-0.008 \\
(-0.935)\end{array}$ & $\begin{array}{l}-0.012^{*} \\
(-1.884)\end{array}$ & $\begin{array}{c}-0.001 \\
(-0.071)\end{array}$ & $\begin{array}{c}-0.040 \\
(-1.225)\end{array}$ & $\begin{array}{c}0.008 \\
(1.417)\end{array}$ & $\begin{array}{c}0.029 * * \\
(2.543)\end{array}$ \\
\hline Year FE & Yes & Yes & Yes & Yes & Yes & Yes & Yes & Yes & Yes \\
\hline Bank FE & Yes & Yes & Yes & Yes & Yes & Yes & Yes & Yes & Yes \\
\hline Observations & 40,147 & 40,147 & 40,147 & 40,147 & 40,147 & 40,147 & 40,147 & 40,147 & 40,147 \\
\hline$R$-squared & 0.047 & 0.023 & 0.017 & 0.016 & 0.013 & 0.024 & 0.005 & 0.084 & 0.034 \\
\hline Banks & 7,844 & 7,844 & 7,844 & 7,844 & 7,844 & 7,844 & 7,844 & 7,844 & 7,844 \\
\hline Number of actions & 1,547 & 1,547 & 1,547 & 1,547 & 1,547 & 1,547 & 1,547 & 1,547 & 1,547 \\
\hline Under-identification & 272.5 & 272.5 & 272.5 & 272.5 & 272.5 & 272.5 & 272.5 & 272.5 & 272.5 \\
\hline Weak-identification & 280.1 & 280.1 & 280.1 & 280.1 & 280.1 & 280.1 & 280.1 & 280.1 & 280.1 \\
\hline Hansen $J$-test & 3.110 & 3.973 & 0.414 & 9.165 & 0.506 & 7.737 & 3.653 & 1.818 & 5.989 \\
\hline$p$-value (Hansen) & 0.375 & 0.264 & 0.937 & 0.0272 & 0.918 & 0.0518 & 0.302 & 0.611 & 0.112 \\
\hline
\end{tabular}

Notes. This table presents the results of IV regressions of enforcement actions in single-market and multi-market banks on lending liquidity creation growth, and their components. Panel A presents the first stage regressions, and Panel B shows the second stage results. The standard errors are clustered on the bank level and the associated $t$-statistics are reported in parentheses. Financial crisis years (2000-2002 and 2007-2009) excluded. *** $\mathrm{p}<0.01, * * \mathrm{p}<0.05, * \mathrm{p}<0.1$ 


\section{Appendix}

The real effects of banking supervision: Evidence from enforcement actions

Table A.5- Bank Representation and External Financial Dependence (multi-market banks included)

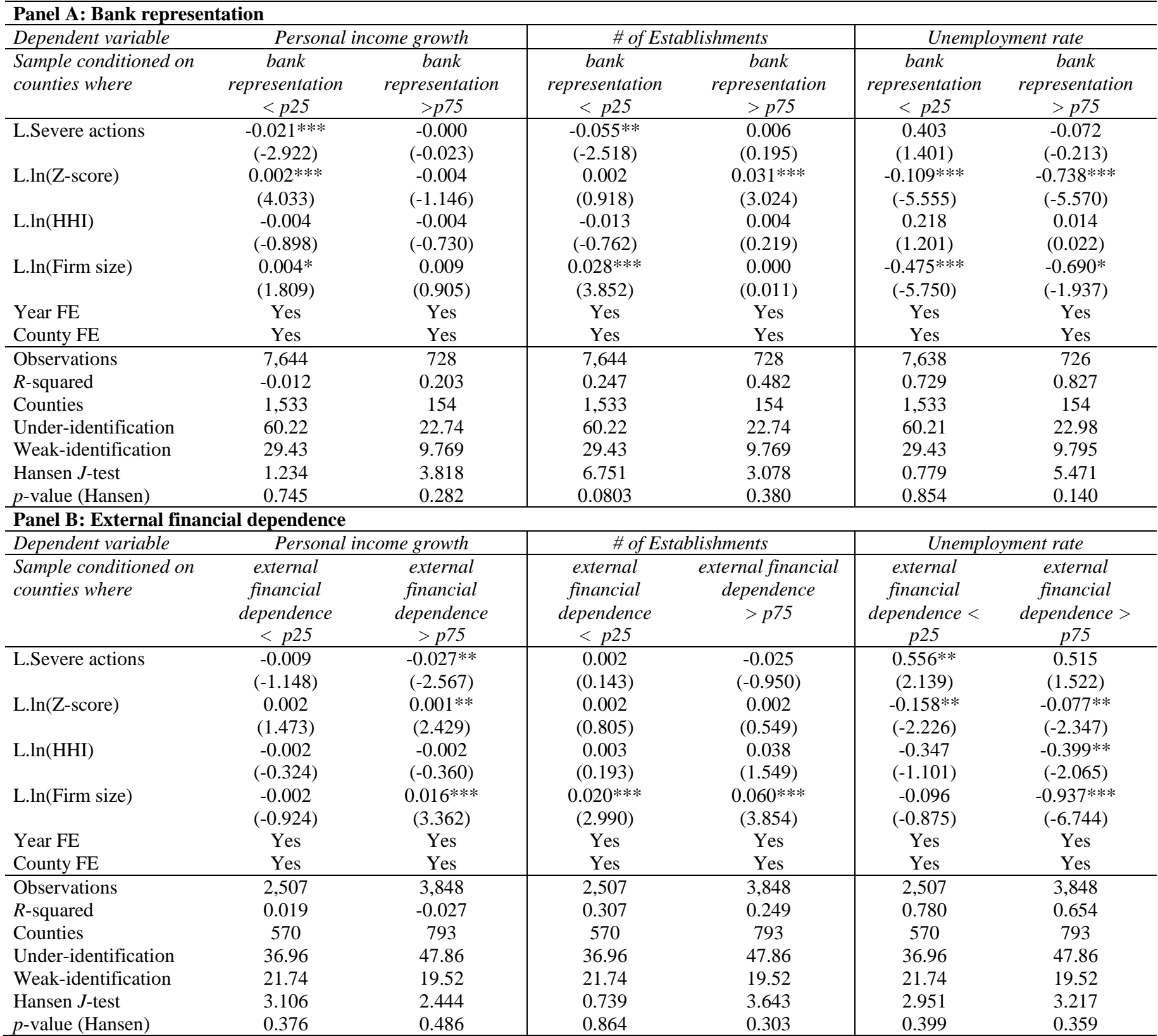

Notes. Similar to Table 8, this table presents complementary evidence that exploits the cross-sectional predictions that the macroeconomic effects should be more pronounced in

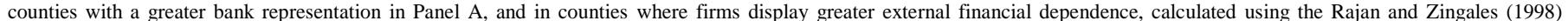

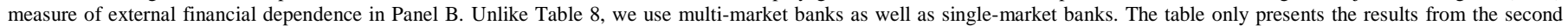

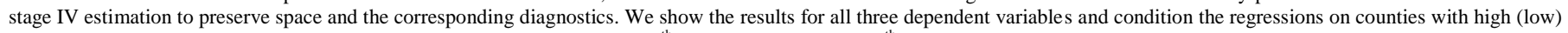
representation of banks, defined as the number of banks being below the $25^{\text {th }}$ percentile (above the $75^{\text {th }}$ percentile) in Panel A. Panel B conditions the regressions on counties whose

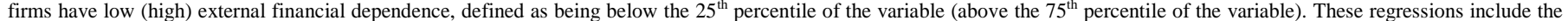

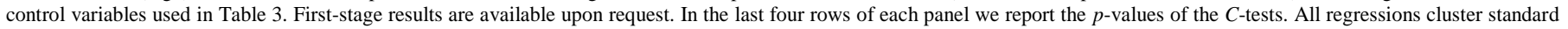
errors on the county level and the associated $t$-statistics are reported in parentheses.. Financial crisis years $(2000-2002$ and $2007-2009)$ excluded. $* * * \mathrm{p}<0.01, * * \mathrm{p}<0.05, * \mathrm{p}<0.1$ 


\section{Appendix}

\section{The real effects of banking supervision: Evidence from enforcement actions}

Table A.6 Long-run effects and the behavior of competitor institutions (multi-market banks included)

\begin{tabular}{|c|c|c|c|c|c|c|c|c|c|}
\hline \multirow[b]{2}{*}{$\overline{D e p e n d e n t ~ v a r i a b l e}$} & \multicolumn{9}{|c|}{ Panel A: Long-run effects } \\
\hline & $\begin{array}{c}\text { Personal income } \\
\text { growth } \\
t+1\end{array}$ & $\begin{array}{c}\text { \# of } \\
\text { Establishments } \\
t+1\end{array}$ & $\begin{array}{c}\text { Unemployment } \\
\text { rate } \\
t+1 \\
\end{array}$ & $\begin{array}{c}\text { Personal income } \\
\text { growth } \\
t+2\end{array}$ & $\begin{array}{c}\text { \# of } \\
\text { Establishments } \\
t+2\end{array}$ & $\begin{array}{c}\text { Unemployment } \\
\text { rate } \\
t+2 \\
\end{array}$ & $\begin{array}{c}\text { Personal income } \\
\text { growth } \\
t+3\end{array}$ & $\begin{array}{c}\text { \# of } \\
\text { Establishments } \\
t+3\end{array}$ & $\begin{array}{c}\text { Unemployment } \\
\text { rate } \\
t+3 \\
\end{array}$ \\
\hline L.Severe actions & $\begin{array}{c}0.001 \\
(0.147)\end{array}$ & $\begin{array}{c}-0.030 * * \\
(-2.041)\end{array}$ & $\begin{array}{c}0.029 \\
(0.172)\end{array}$ & $\begin{array}{c}-0.001 \\
(-0.075)\end{array}$ & $\begin{array}{c}0.003 \\
(0.233)\end{array}$ & $\begin{array}{c}0.066 \\
(0.601)\end{array}$ & $\begin{array}{c}0.009 \\
(1.149)\end{array}$ & $\begin{array}{c}-0.028^{* *} \\
(-2.391)\end{array}$ & $\begin{array}{l}0.357^{*} \\
(1.932)\end{array}$ \\
\hline L.ln(Z-score) & $\begin{array}{l}0.001^{*} \\
(1.857)\end{array}$ & $\begin{array}{c}0.006 * * * \\
(2.839)\end{array}$ & $\begin{array}{c}-0.118 * * * \\
(-6.833)\end{array}$ & $\begin{array}{l}-0.002^{*} \\
(-1.790)\end{array}$ & $\begin{array}{c}-0.002 \\
(-0.471)\end{array}$ & $\begin{array}{c}0.112 * * * \\
(5.225)\end{array}$ & $\begin{array}{c}-0.000 \\
(-0.372)\end{array}$ & $\begin{array}{c}-0.003 \\
(-1.012)\end{array}$ & $\begin{array}{c}0.142 * * * \\
(3.629)\end{array}$ \\
\hline L. $\ln (\mathrm{HHI})$ & $\begin{array}{c}0.018 * * * \\
(6.189)\end{array}$ & $\begin{array}{c}0.044 * * * \\
(3.494)\end{array}$ & $\begin{array}{l}-0.251 * * \\
(-2.273)\end{array}$ & $\begin{array}{c}0.010 * * \\
(2.166)\end{array}$ & $\begin{array}{l}0.018 \\
(1.226)\end{array}$ & $\begin{array}{c}0.064 \\
(0.865)\end{array}$ & $\begin{array}{l}0.007 * \\
(1.657)\end{array}$ & $\begin{array}{l}0.009 \\
(0.903)\end{array}$ & $\begin{array}{c}0.027 \\
(0.208)\end{array}$ \\
\hline L.ln(Firm size) & $\begin{array}{l}0.004 * * \\
(2.146)\end{array}$ & $\begin{array}{c}0.023 * * * \\
(2.926)\end{array}$ & $\begin{array}{c}-0.338 * * * \\
(-5.583)\end{array}$ & $\begin{array}{c}0.003 \\
(1.203)\end{array}$ & $\begin{array}{c}-0.010 \\
(-1.345)\end{array}$ & $\begin{array}{l}0.111 * * \\
(1.983)\end{array}$ & $\begin{array}{c}0.003 \\
(1.522)\end{array}$ & $\begin{array}{c}-0.002 \\
(-0.294)\end{array}$ & $\begin{array}{c}0.153 \\
(1.614)\end{array}$ \\
\hline $\begin{array}{l}\text { Year FE } \\
\text { Year FE }\end{array}$ & $\begin{array}{l}\text { Yes } \\
\text { Yes }\end{array}$ & $\begin{array}{l}\text { Yes } \\
\text { Yes }\end{array}$ & $\begin{array}{l}\text { Yes } \\
\text { Yes }\end{array}$ & $\begin{array}{l}\text { Yes } \\
\text { Yes }\end{array}$ & $\begin{array}{l}\text { Yes } \\
\text { Yes }\end{array}$ & $\begin{array}{l}\text { Yes } \\
\text { Yes }\end{array}$ & $\begin{array}{l}\text { Yes } \\
\text { Yes }\end{array}$ & $\begin{array}{l}\text { Yes } \\
\text { Yes }\end{array}$ & $\begin{array}{l}\text { Yes } \\
\text { Yes }\end{array}$ \\
\hline Observations & 13,736 & 13,736 & 13,722 & 11,162 & 11,162 & 11,148 & 11,170 & 11,170 & 11,163 \\
\hline$R$-squared & 0.082 & 0.308 & 0.726 & 0.115 & 0.067 & 0.344 & 0.352 & 0.306 & 0.788 \\
\hline Number of banks & 2,828 & 2,828 & 2,828 & 2,808 & 2,808 & 2,808 & 2,815 & 2,815 & 2,815 \\
\hline Under-identification & 136.6 & 136.6 & 135.8 & 88.09 & 88.09 & 87.53 & 88.10 & 88.10 & 87.67 \\
\hline Weak-identification & 61.88 & 61.88 & 61.41 & 48.03 & 48.03 & 47.66 & 48.03 & 48.03 & 47.67 \\
\hline Hansen- $J$-test & 0.527 & 2.123 & 1.895 & 0.749 & 1.958 & 2.087 & 4.207 & 2.898 & 5.621 \\
\hline$p$-value (Hansen) & 0.913 & 0.547 & 0.595 & 0.862 & 0.581 & 0.555 & 0.240 & 0.408 & 0.132 \\
\hline
\end{tabular}

Panel B: Behavior of competitor banks

\begin{tabular}{|c|c|c|c|c|c|c|c|c|c|c|c|c|}
\hline \multirow{2}{*}{ Dependent variable } & & & \multirow{2}{*}{\multicolumn{3}{|c|}{ Total lending growth }} & \multirow{2}{*}{\multicolumn{3}{|c|}{ Liquidity creation growth }} \\
\hline & ${ }_{t+1}^{\text {Total }}$ & $\begin{array}{l}\text { ding (mark } \\
t+2\end{array}$ & $\begin{array}{l}\text { zare) } \\
t+3\end{array}$ & $\underset{t+1}{L i q u i}$ & $\begin{array}{l}t+2 \\
\text { eaton }\end{array}$ & & & & & & $t+2$ & vth $t+3$ \\
\hline \multirow{2}{*}{ L.Severe actions } & -0.000 & -0.000 & -0.000 & -0.000 & -0.000 & -0.000 & -0.001 & -0.000 & 0.000 & 0.001 & 0.006 & -0.010 \\
\hline & $(-0.839)$ & $(-0.223)$ & $(-0.105)$ & $(-0.678)$ & $(-0.647)$ & $(-1.097)$ & $(-1.162)$ & $(-0.116)$ & $(0.445)$ & $(0.177)$ & $(0.339)$ & $(-0.805)$ \\
\hline \multirow[t]{2}{*}{ L.In(Z-score) } & $-0.000 * *$ & -0.000 & -0.000 & $-0.000 * *$ & $-0.000 * *$ & $-0.000 * * *$ & $-0.000 * * *$ & -0.000 & -0.000 & -0.000 & -0.000 & -0.000 \\
\hline & $(-2.040)$ & $(-1.137)$ & $(-1.606)$ & $(-2.043)$ & $(-2.023)$ & $(-2.727)$ & $(-2.812)$ & $(-0.133)$ & $(-1.001)$ & $(-0.774)$ & $(-0.171)$ & $(-0.821)$ \\
\hline \multirow[t]{2}{*}{ L.ln(HHI) } & -0.000 & -0.000 & -0.000 & -0.000 & -0.000 & -0.000 & 0.000 & 0.000 & -0.000 & -0.002 & -0.001 & 0.000 \\
\hline & $(-1.163)$ & $(-0.938)$ & $(-1.162)$ & $(-0.859)$ & $(-1.255)$ & $(-0.837)$ & $(0.810)$ & $(0.394)$ & $(-0.721)$ & $(-1.347)$ & $(-0.372)$ & $(0.004)$ \\
\hline \multirow[t]{2}{*}{ L.ln(Firm size) } & 0.000 & 0.000 & $0.000^{*}$ & 0.000 & 0.000 & 0.000 & $-0.000 *$ & 0.000 & 0.000 & -0.009 & 0.004 & 0.001 \\
\hline & $(0.395)$ & (1.222) & $(1.801)$ & $(0.352)$ & $(1.278)$ & $(1.428)$ & $(-1.791)$ & $(0.646)$ & $(0.058)$ & $(-1.025)$ & $(1.052)$ & $(0.508)$ \\
\hline Year FE & Yes & Yes & Yes & Yes & Yes & Yes & Yes & Yes & Yes & Yes & Yes & Yes \\
\hline Bank FE & Yes & Yes & Yes & Yes & Yes & Yes & Yes & Yes & Yes & Yes & Yes & Yes \\
\hline Observations & 32,558 & 28,173 & 27,122 & 32,558 & 28,173 & 27,122 & 32,558 & 28,173 & 27,122 & 32,558 & 28,173 & 27,122 \\
\hline$R$-squared & 0.007 & 0.010 & 0.007 & 0.005 & 0.008 & 0.002 & 0.013 & 0.000 & 0.010 & 0.000 & 0.000 & 0.000 \\
\hline Number of banks & 6,540 & 6,216 & 5,987 & 6,540 & 6,216 & 5,987 & 6,540 & 6,216 & 5,987 & 6,540 & 6,216 & 5,987 \\
\hline Under-identification & 146.0 & 112.3 & 105.6 & 146.0 & 112.3 & 105.6 & 146.0 & 112.3 & 105.6 & 146.0 & 112.3 & 105.6 \\
\hline Weak-identification & 131.5 & 125.8 & 121.0 & 131.5 & 125.8 & 121.0 & 131.5 & 125.8 & 121.0 & 131.5 & 125.8 & 121.0 \\
\hline Hansen- $J$-test & 1.244 & 4.435 & 3.911 & 1.686 & 3.781 & 3.260 & 5.400 & 0.600 & 1.233 & 7.561 & 3.237 & 1.966 \\
\hline$p$-value (Hansen) & 0.743 & 0.218 & 0.271 & 0.640 & 0.286 & 0.353 & 0.145 & 0.896 & 0.745 & 0.0560 & 0.357 & 0.579 \\
\hline
\end{tabular}

Notes. Panel A presents instrumental variable regressions that establish the long-run effects of severe enforcement actions on personal income growth, the number of establishments, and the unemployment rate. The dependent variables are
forwarded one, two, and three years. Panel B examines the behavior of competitor banks' market shares in terms of total lending and liquidity creation, and the corresponding growth rates for one, two, and three years following the announcements of severe enforcement actions using instrumental variable regressions. The control variables discussed in the notes to Table 3 are included. We only show second-stage results. First-stage results are available upon request. The standard errors are clustered on the county and bank level respectively, and the associated $t$-statistics are reported in parentheses. Financial crisis years $(2000-2002$ and $2007-2009)$ excluded. $* * * \mathrm{p}<0.01, * * \mathrm{p}<0.05, * \mathrm{p}<0.1$. 